\title{
22. KINEMATICS AND MECHANICS OF THE INDIAN OCEAN DIFFUSE PLATE BOUNDARY ZONE ${ }^{1}$
}

\author{
Carol A. Stein, ${ }^{2}$ Sierd Cloetingh, ${ }^{3}$ and Rinus Wortel ${ }^{4}$
}

\begin{abstract}
We review data and models for the recent tectonics of the region in the northern Indian Ocean from the Central Indian Ridge to the Sumatra Trench, long considered an anomalous tectonic region. Seismicity is much greater than expected for an area not traditionally considered to be a plate boundary, and the crust and sediments are deformed by both folding and faulting. Recently these phenomena, previously considered examples of deformation within a nonrigid Indo-Australian Plate, have been explained in terms of rigid plate tectonics. Analysis of relative plate motion data along the Carlsberg and Central Indian Ridges indicates the presence of distinct Indian and Australian plates. The seismicity and deformation thus reflect a diffuse boundary between these two rigid plates. This plate motion model eliminates the nonclosure of the Indian Ocean triple junction. The kinematic models, which describe the present-day plate motions, do not directly address the mechanics of the formation of the diffuse plate boundary. Further insight can be obtained from mechanical models of the stresses in the Central Indian Basin, including ones based on plate driving forces. The predicted stresses are consistent with the diffuse boundary model and distribution of deformation shown by seismicity, and by marine geophysical and satellite gravity data. Furthermore, they provide an explanation for the widespread pattern of compressional folding east, west, and on the Ninetyeast Ridge. These data and the kinematic and mechanical models provide insight into three enigmatic tectonic features: the complex blocky structure of the Ninetyeast Ridge north of $10^{\circ} \mathrm{S}$, the trend of the southernmost $85^{\circ} \mathrm{E}$ Ridge, and the rapid recent subsidence of the southern Chagos-Laccadive Ridge.
\end{abstract}

\section{INTRODUCTION}

The northeastern Indian Ocean has unusually high seismicity compared to most intraplate regions (Gutenberg and Richter, 1954; Stover, 1966; Rothe, 1969; Sykes, 1970; Stein and Okal, 1978; Stein, 1978; Wiens and Stein, 1983; 1984; Bergman et al., 1984; Bergman and Solomon, 1984; 1985; Wiens, 1986; Petroy and Wiens, 1989). Concentrations of earthquakes occur near the Ninetyeast and Chagos-Laccadive ridges, and others are distributed throughout a wide region Fig. 1). The focal mechanisms show a pattern of faulting varying from both normal and strike-slip between the Central Indian and Carlsberg ridges and the Chagos-Laccadive Ridge, to thrust and strike-slip faulting eastward to the Sumatra subduction zone.

In the Central Indian and Wharton basins, the region of diffuse seismicity corresponds approximately to the area of the faulted and folded sediments and crust (Curray and Moore, 1971; Moore et al., 1974; Eittreim and Ewing, 1972; Weissel et al., 1980; Geller et al., 1983; Neprochnov et al., 1988; Shcherbakov et al., 1989; Stein et al., 1989). The sediments and acoustic basement are deformed into longwavelength $(\sim 200 \mathrm{~km})$ undulations with $\sim 1 \mathrm{~km}$ maximum amplitudes, measured from the offset of top of the sediment or acoustic basement. Superimposed on the folding are closely spaced faults. The fault blocks are sometimes $5-20 \mathrm{~km}$ across with crustal offsets up to $0.5 \mathrm{~s}$ of two-way traveltime $(>500 \mathrm{~m})$ on the bounding faults (Shipboard Scientific Party, 1987). The folds are associated with large (30-80 mgal) free-air gravity

\footnotetext{
${ }^{1}$ Cochran, J. R., Stow, D.A.V., et al., 1990. Proc. ODP, Sci. Results, 116: College Station, TX (Ocean Drilling Program).

2 Department of Geological Sciences, University of Illinois at Chicago, Chicago, IL 60680, U.S.A

${ }^{3}$ Institute of Earth Sciences, Free University, P.O. Box 7161, 1007 MC Amsterdam, The Netherlands.

${ }^{4}$ Institute of Earth Sciences, University of Utrecht, P.O. Box 80.021, 3508 TA Utrecht, The Netherlands.
}

anomalies (Weissel et al., 1980) and geoid anomalies with amplitudes up to $\sim 2 \mathrm{~m}$ (McAdoo and Sandwell, 1985) (Fig. 2). In addition, the heat flow within the deformed zone in the Central Indian Basin is higher than expected for its age (Anderson et al, 1977; Geller et al., 1983; Stein et al., 1988). On average, the heat flow in the Wharton Basin is that expected for its age (Stein et al., 1988). A relative heat flow high $\sim 200 \mathrm{~km}$ seaward of the Sumatra Trench axis, and rapid spatial heat-flow variations, possibly due to hydrothermal circulation associated with the deformation, have been reported (Lawver and Taylor, 1987).

A widespread unconformity in the Central Indian Basin identified by Curray and Moore (1971) has been dated at DSDP Site 218 Fig. 1) as uppermost Miocene (Moore et al., 1974), at three piston core sites (on topographic highs that have probably received only pelagic sediments since uplift) as uppermost Miocene/lowermost Pliocene (Weissel et al., 1980; Geller et al., 1983), and at ODP Leg 116 sites at $\sim 7.5 \mathrm{Ma}$ (Cochran, this volume). Hence this surface, as traced on seismic reflection records, appears to have been formed at approximately the same time across the Bengal Fan southward from Sri Lanka and DSDP Site 218 to the southern edge near $7^{\circ} \mathrm{S}$ (Curray and Munasinghe, 1989). This regional unconformity presumably dates the initiation of deformation in the northeastern Indian Ocean.

In this paper we review two approaches to understanding the origin of the deformation. First, we discuss the evolution of ideas on the regional kinematics from models pointing to intraplate deformation and nonrigid plate tectonics to the recent plate tectonic models with a diffuse boundary between Indian and Australian plates. We then consider mechanical models for lithospheric deformation and the stresses predicted by plate driving forces.

\section{KINEMATICS OF THE DEFORMATION}

The evolution of models for the kinematics of the Central Indian Ocean region is shown in Figure 3. Prior to the 


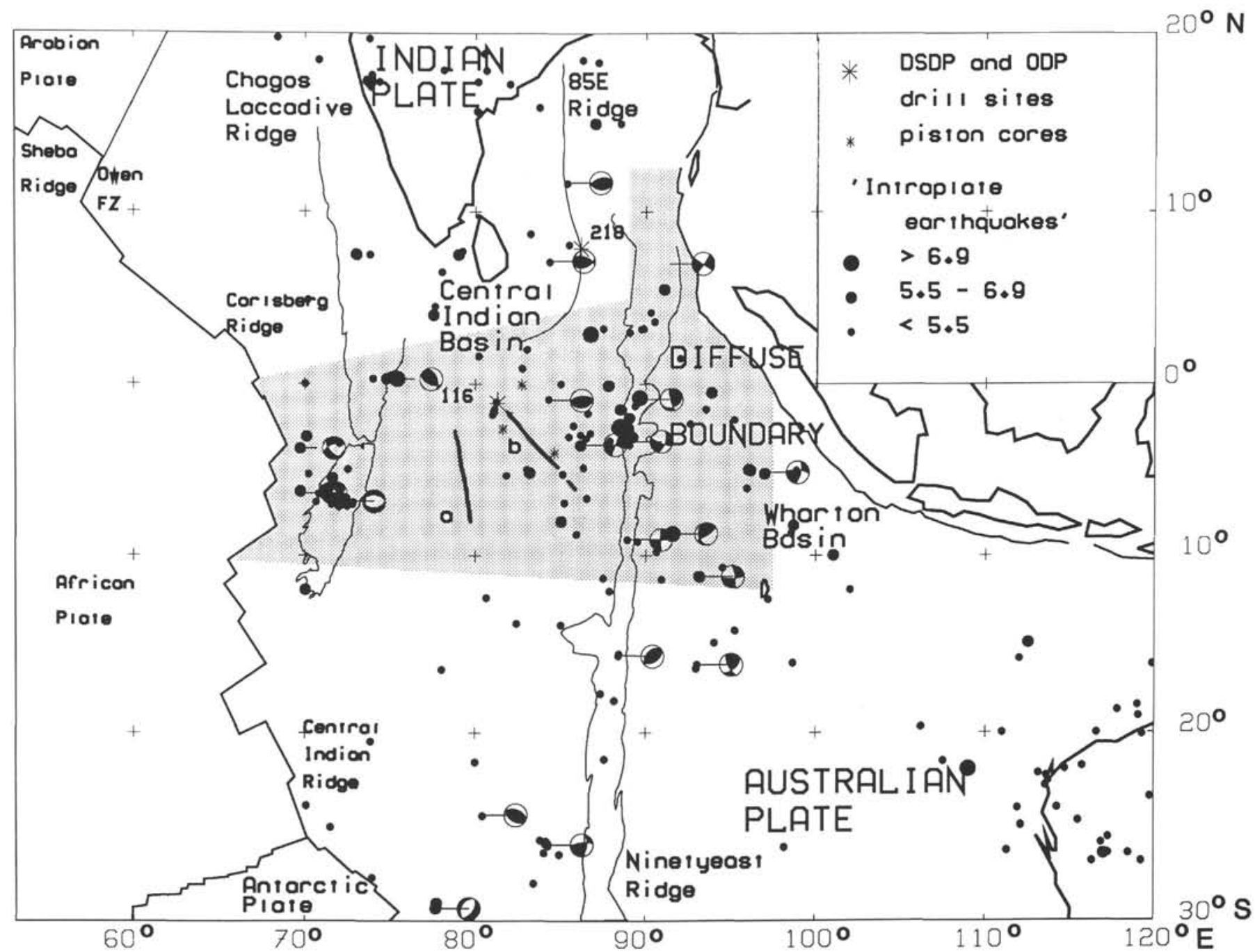

Figure 1. Intraplate seismicity, focal mechanisms, plate boundaries, and major seafloor features for the northeastern Indian Ocean. The shaded region is the diffuse plate boundary between the Indian and Australian plates. For convenience we describe the Wharton Basin as the region east of the Ninetyeast Ridge. Focal mechanisms from Stein (1978), Wiens and Stein (1983, 1984), Bergman, et al. (1984), Bergman and Solomon (1984, 1985), Wiens (1986), Petroy and Wiens (1989), and Stein and Weissel (in press). Some of the epicenters are from relocations by Wiens (1986) and Petroy and Wiens (1989).

development of plate tectonics, Gutenberg and Richter (1954) noted an unusual concentration of activity near the southern end of the Chagos Ridge and the northern Ninetyeast Ridge. Sykes (1970) suggested that this seismicity reflected an incipient island arc extending from Sri Lanka to Australia, possibly related to a westward change in the location of the Sumatra subduction zone. Subsequent focal mechanism studies (Fitch, 1972; Stein and Okal, 1978; Bergman and Solomon, 1985) showed strike-slip motion within the proposed nascent subduction zone. Stein and Okal (1978) suggested that the leftlateral strike slip faulting along the northern Ninetyeast Ridge represents relative motion between the eastern and western halves of the Indo-Australian Plate, with a boundary extending northward from the southeast Indian Ridge. This slip, estimated at $\sim 20 \mathrm{~mm} / \mathrm{yr}$ from seismic moments, was thought to result from the greater resistance along the Himalayan zone of continental collision compared to the plate portion subducted beneath the Indonesian Arc. Based on a reanalysis of the earthquake data, including hypocentral locations and seismic moments, Petroy and Wiens (1989) concluded that the slip is $\sim 2.8 \mathrm{~mm} / \mathrm{yr}$.
Relative plate motion models provide additional insight. If three plates meeting at a triple junction act rigidly, the three Euler vectors describing their relative motions must sum to zero, within the uncertainties of the velocity estimates. Minster and Jordan (1978), however, noted that the Indian Ocean triple junction (between Africa, Antarctica, and Indo-Australia) had significant non-closure, which could be reduced by separating the Indo-Australian Plate into two portions, perhaps with a boundary near the Ninetyeast Ridge, as implied by the seismicity. The improved fit to the data introduced by splitting the Indo-Australian Plate is statistically significant (Stein and Gordon, 1984).

Three major problems were not explained by this model. First, the Ninetyeast Ridge being a transform boundary between two plates was incompatible with the observation that the high seismicity and associated blocky morphology of the ridge did not extend south of $\sim 10^{\circ} \mathrm{S}$. Second, this model did not explain the normal faulting earthquakes near the Chagos Bank. Third, it did not explain the diffuse seismicity throughout the Central Indian and Wharton basins. 


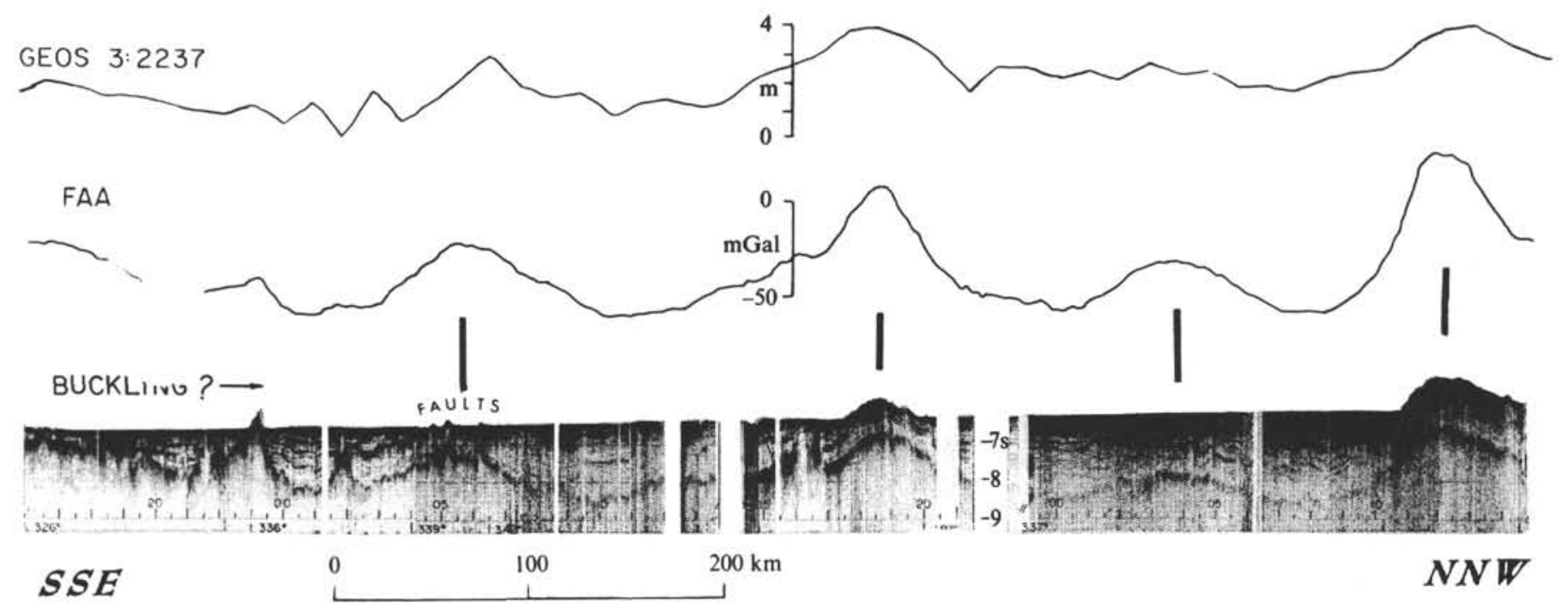

Figure 2. Seismic reflection record showing broad-scale deformation of the sediment and oceanic crust beneath the southern portion of the Central Indian Basin (location shown in Figure 1 by line labeled "b"). Large-amplitude free-air gravity anomalies FAA) and small-amplitude geoidal undulations (GEOS) correlate with acoustic basement deformation (Weissel et al., 1980).

Subsequent studies resolved these problems by using a plate geometry in which distinct Indian and Australian Plates are separated by a diffuse plate boundary extending from the intersection of the Central Indian and Carlsberg Ridges to the Sumatra subduction zone (Wiens et al., 1985). Although previous models treated the Carlsberg and Central Indian ridges as portions of a single AfricaIndo/Australia plate boundary, analysis of the variation in spreading rates showed that a Euler vector derived from the Central Indian Ridge (CIR) data did not predict the rates along the Carlsberg and Sheba (Gulf of Aden Spreading Center) Ridges (Fig. 4). Similarly, an Euler vector derived from Carlsberg and Sheba (Gulf of Aden Spreading Center) Ridges does not fit the CIR data. The Carisberg and Central Indian ridges are thus boundaries between different plate pairs: the Carlsberg separating Africa from India, and the CIR separating Africa from Australia.

The difference between the Africa-India and Africa-Australia Euler vectors gives an Australia-India Euler vector that predicts (Fig. 3, top-right and bottom-right panels) the motion between Australian and Indian plates. North-south extension should occur along the boundary near the CIR and the Chagos-Laccadive Ridge, and north-south compression would occur in the Central Indian Basin. For a boundary segment along the Ninetyeast Ridge, strike slip and/or thrusting motion would occur. As these predictions are in accord with the focal mechanism, marine geophysical, and satellite gravity observations, these phenomena apparently define a diffuse boundary zone between Australian and Indian plates. This model has the attractive features that the existence of separate Australian and Indian plates, the location of the intersection of the boundary with the Central Indian Ridge, and the motion between the two plates are all predicted entirely from the spreading-center observations. The agreement with the observed motion in the diffuse boundary zone provides strong support for the model. Moreover, this plate geometry significantly reduced the nonclosure of the Indian Ocean triple junction.

This analysis has been subsequently extended. DeMets et al. (1988) recalculated the India-Australian motion with an improved magnetic anomaly data set. Their Euler vectors eliminate the nonclosure of the Indian Ocean triple junction, showing that the India-Australia-Africa three-plate system requires no deviation from rigid plate tectonics. In their words, "the absence of significant nonclosure argues against the usefulness of a model of deformation distributed throughout an Indo-Australian plate, but favors a model in which the significant deformation occurs in a diffuse plate boundary along the equatorial Indian Ocean between the Central Indian Ridge and the Sumatra Trench." Specifically, for the diffuse boundary extending eastward near the Equator from the Central Indian Ridge, north-south extension with a rate of $\sim 6$ $\mathrm{mm} / \mathrm{yr}$ would occur near the CIR and the Chagos-Laccadive Ridge and north-south compression from $\sim 10^{\circ} \mathrm{S}-7^{\circ} \mathrm{N}, 85^{\circ} \mathrm{E}$ with a rate of $\sim 4 \mathrm{~mm} / \mathrm{yr}$ would occur in the Central Indian Basin (Gordon et al., in press). These rates are somewhat less than calculated by Wiens et al. (1985). The difference between the Euler vectors calculated by Wiens et al., (1985) and Gordon et al. (in press) depends only weakly on whether India and Arabia are treated as one or two plates, but strongly depends on the differences between the old data and newer, improved data used in the analysis of Gordon et al. (in press). The Euler vector for Australia-India relative motion as calculated using only Indian Ocean data by Gordon et al. (in press) is very similar to the NUVEL-1 Euler vector based on an inversion of the global relative motion data. Hence, the deformation in the Indian Ocean can be considered as a plate boundary process, albeit diffuse, as such requiring no deviation from rigid plate tectonics.

Defining the precise location of the diffuse boundary zone is difficult, as only the boundary intersection with the CIR is given by the magnetic data. How the boundary extends to the east has been inferred from seismicity and sediment and crustal deformation. The estimates of slip from seismic moments (Petroy and Wiens, 1989) suggest significant strain within the Wharton Basin. Although slightly different locations have been proposed, Petroy and Wiens (1989), Stein et al. (1989), and Gordon et al. (in press) agree that the boundary probably extends from the CIR to the Sumatra Trench near its intersection with the Investigator Fracture Zone $\left(\sim 98^{\circ} \mathrm{E}\right)$. If so, although the Ninetyeast Ridge may provide a weak zone of preferential deformation and seismicity, it does not mark the eastern limit of the diffuse boundary as was assumed by Wiens et al. (1985) and Stein et al. (1988). 
華
OE \& CHAGOS ANOMALOUS SEISMICITY

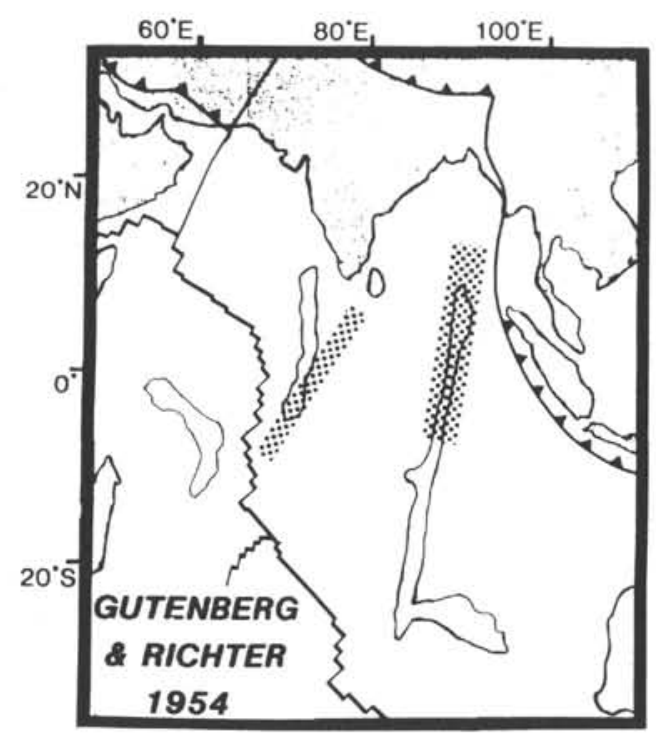

INDIA - AUSTRALIA MOTION ALONG MOE

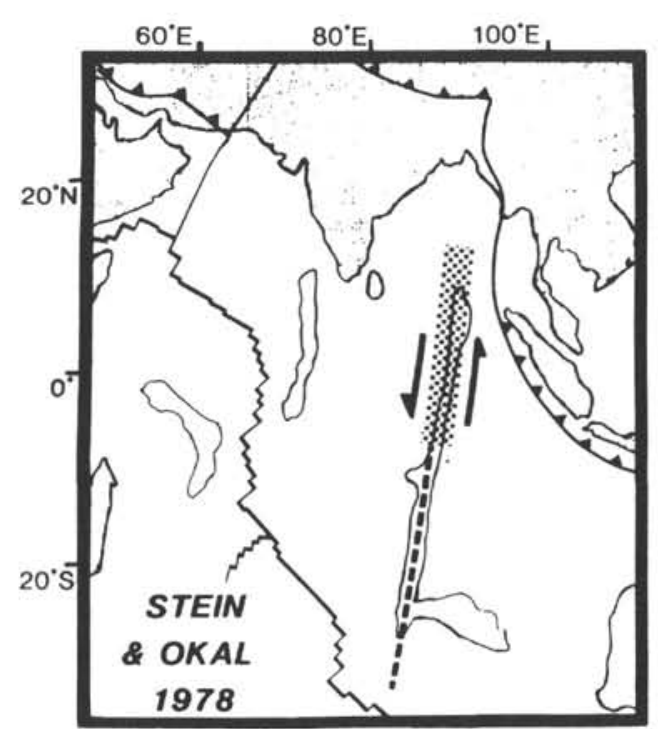

CEYLON - AUSTRALIA

NASCENT ARC

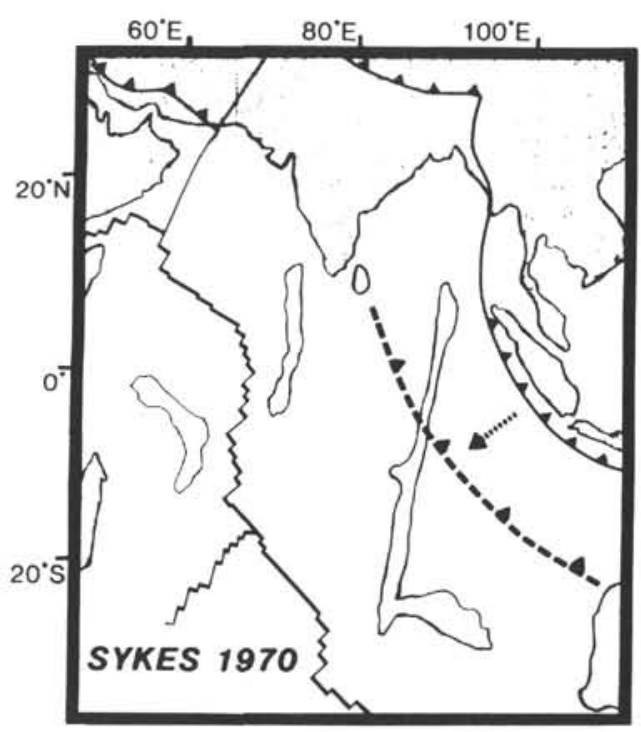

CIR - SUMATRA DIFFUSE BOUNDARY

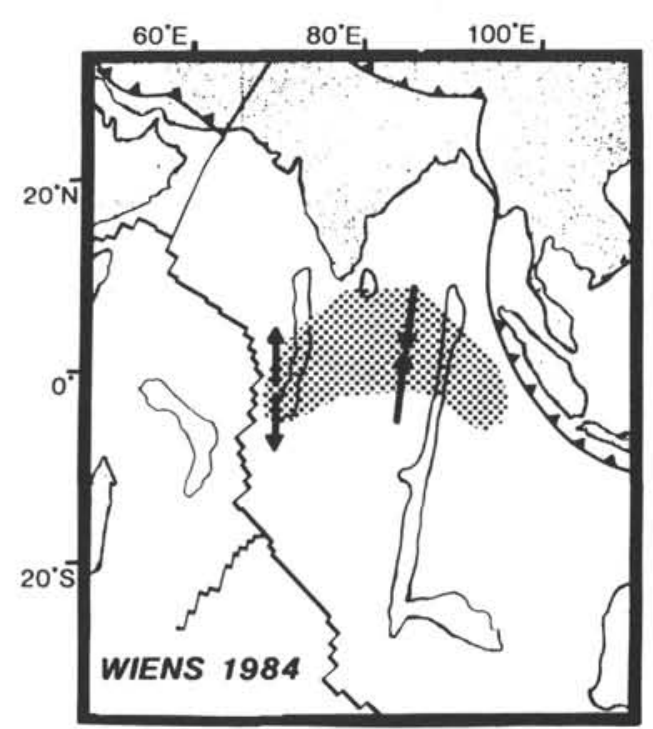

PLATE MOTION INVERSION MODELS
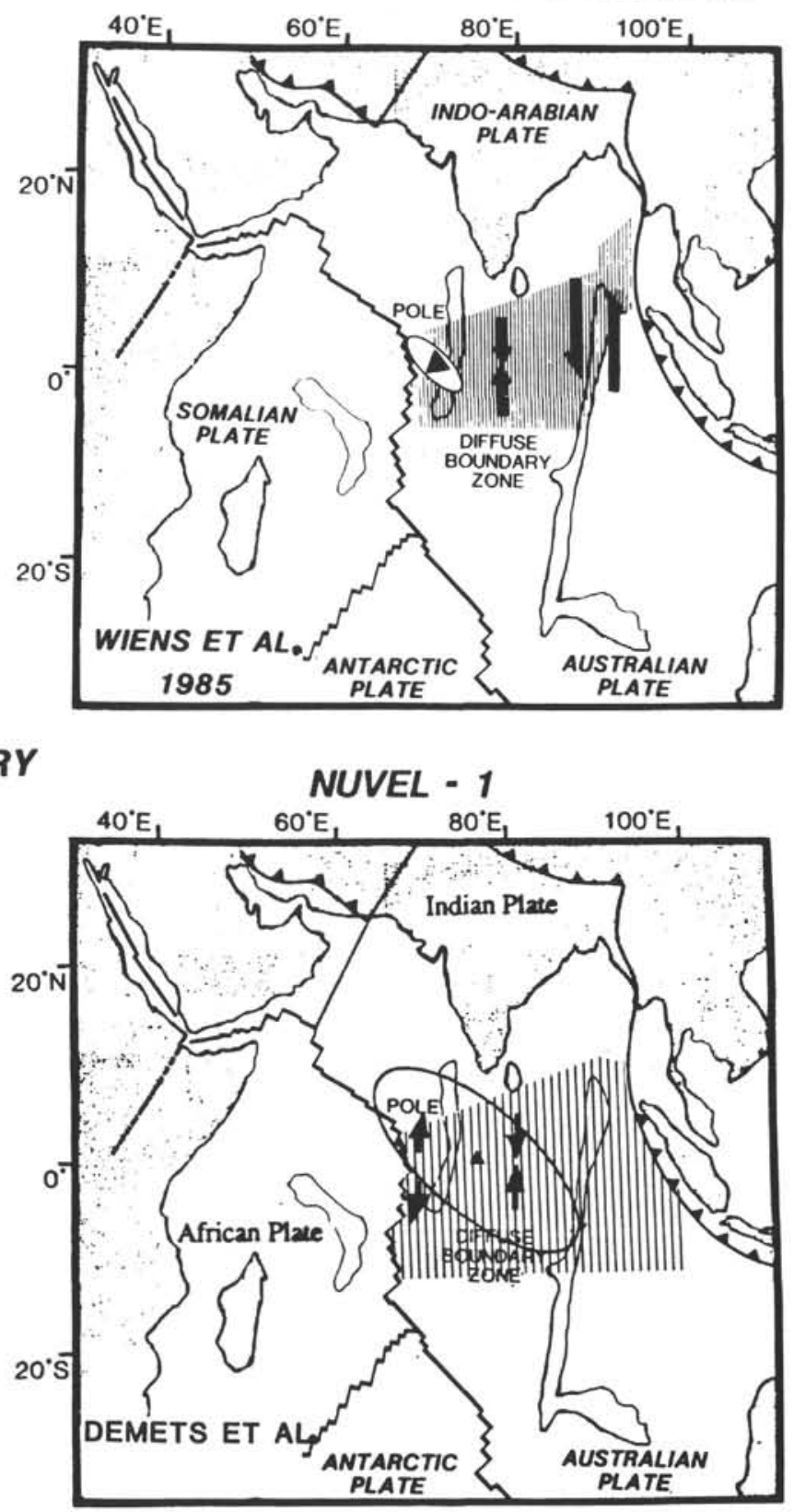

Figure 3. Schematic diagrams illustrating the historical development of tectonic models for the northern Indian Ocean. Modified from Wien et al. (1986). 
A

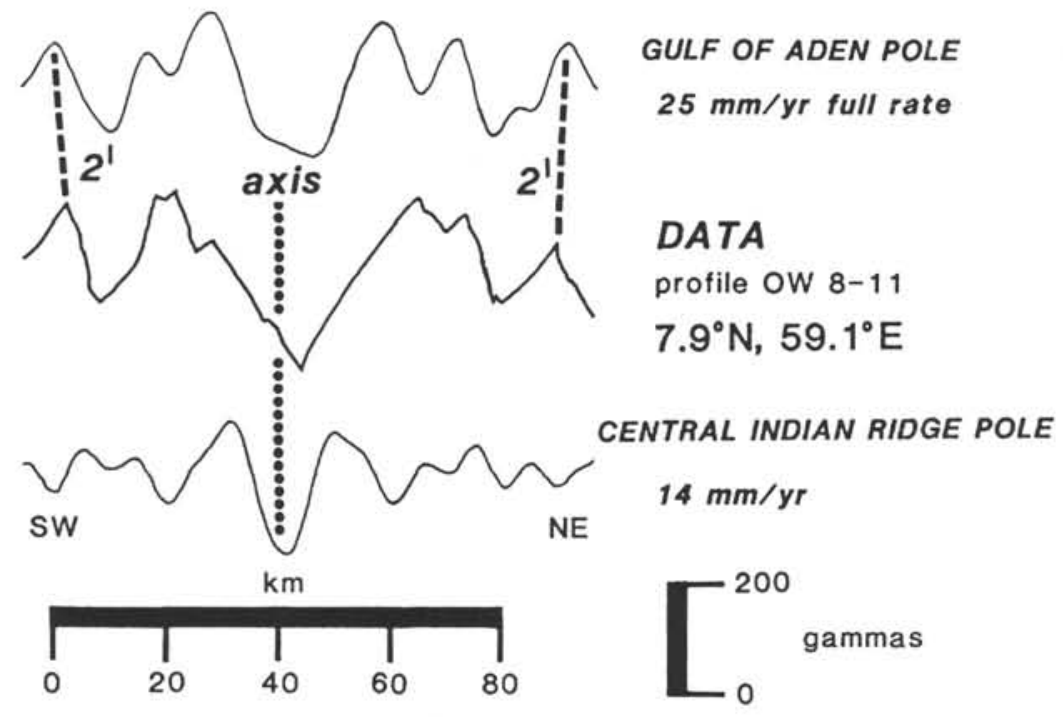

B
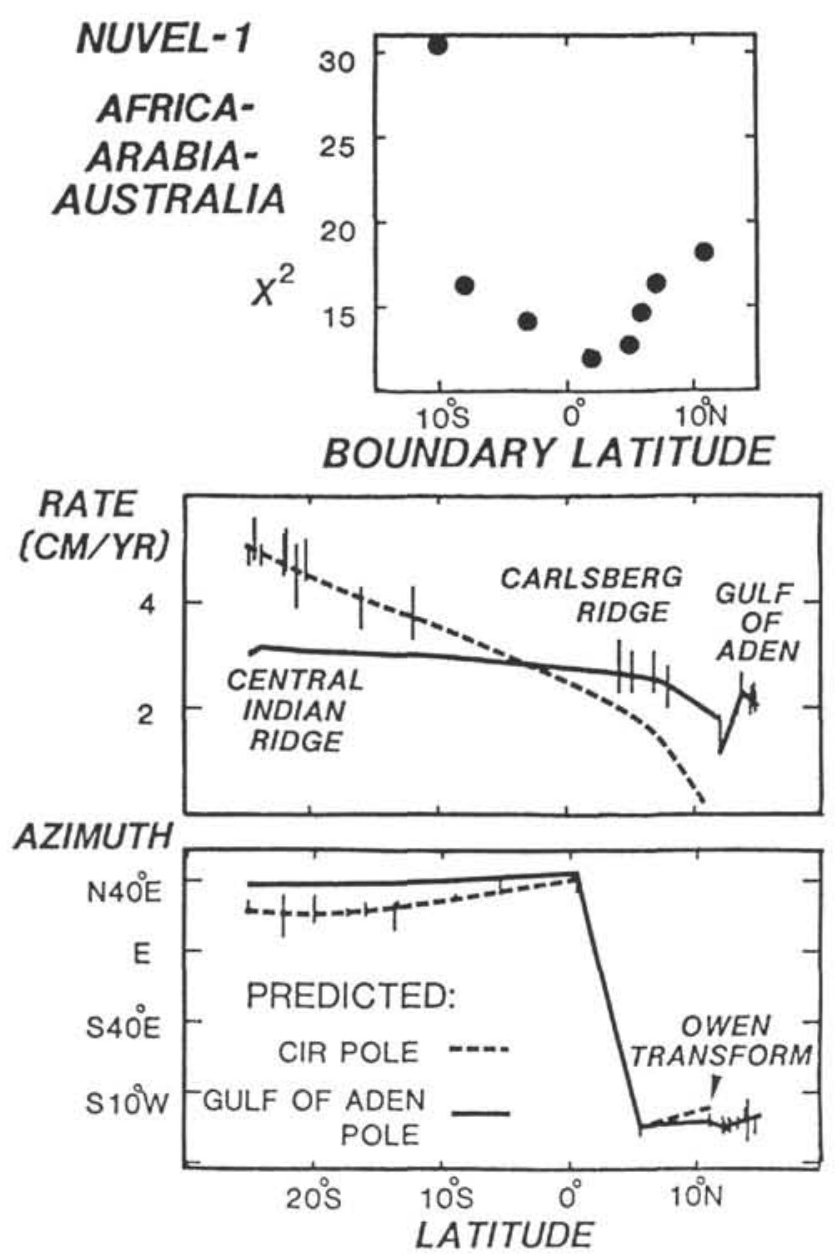

Figure 4. A. Carlsberg Ridge magnetic anomalies. Synthetic anomalies for $25 \mathrm{~mm} / \mathrm{yr}$ full rate predicted by the Euler vector for the Gulf of Aden, fit the observed data better than the slower rate predicted from the Central Indian Ridge data (after Wiens et al., 1985). B. (Top) plate kinematic test of the proposed boundary geometry (after Wiens et al., 1985). (Middle) misfit to relative motion data as a function of the assumed location of the boundary between the Indo-Arabian and Australian plates. The minimum misfit occurs for a boundary between $4^{\circ} \mathrm{N}$ and the Equator. (Bottom) rate and azimuth data along the boundary separating Africa from plates to the east. The Carlsberg Ridge rates and Owen Transform azimuth are better fit by the predictions of a pole from the Gulf of Aden data (solid line) than those for a pole from the Central Indian Ridge data (dashed line). 
Gordon et al. (in press) have shown that the cumulative deformation estimated from seismicity and seismic reflection records is compatible with the Indian/Australian motion pole for present-day motions maintained over the last $7.5 \mathrm{Ma}$. Also, Leg 116 drilling results suggest that the deformation has been more or less continuous since its initiation at $7.5 \mathrm{Ma}$ (Cochran, this volume). As noted by Gordon et al. (in press), in the Central Indian Basin the folding can only account for a few kilometers of horizontal shortening (substantially less than predicted by the Euler vector for Australian-Indian motion) and they suggest that much of the shortening may occur by reverse faulting. Many reverse faults are observed on seismic reflection records (Weissel et al., 1980; Geller et al., 1983).

\section{MECHANICS OF THE DEFORMATION}

Although the diffuse boundary model explains the deformation's location and sense of faulting, it is a kinematic model and hence does not address the mechanics of the diffuse plate boundary. Insight into the mechanics can be obtained from several approaches. The shape of the folding reflects the rheology and applied stresses. In addition, constraints on models of the plate driving forces can be derived from the state of stress within a plate (Richardson et al., 1979). Models for the mechanics of the deformation can thus be compared to the principal stress directions inferred from focal mechanism solutions and the orientation, distribution, and magnitude of the faulting and folding.

The temperature structure is important in determining the lithospheric strength (Goetze, 1978; Goetze and Evans, 1979) and hence stress and deformation. This issue is relevant for the Central Indian Basin, as the heat flow is about 10-40 $\mathrm{mW} / \mathrm{m}^{2}$ greater than expected for its age (Geller et al., 1983; Stein et al., 1988). Attempts have thus been made to understand the origin of the additional heat and to determine if the temperatures at depth are significantly greater than predicted by thermal models (e.g. Parsons and Sclater, 1977).

\section{Lithospheric Temperatures}

The temperature distribution with depth can be constrained by combining heat flow, bathymetry, and seismicity data (Fig. 5). The heat-flow constrains the near-surface temperature distribution. The bathymetric depths for the Central Indian Basin, on average those expected for these lithospheric ages after corrections for sediment loads (Cochran and Talwani, 1977; Stein, 1984) (Fig. 6), constrain the integral of the temperature with depth. As the depths of oceanic intraplate earthquakes appear to be limited by an isotherm $\sim 750^{\circ} \mathrm{C}$ (Chen and Molnar, 1983; Wiens and Stein, 1983) (Fig. 7), the maximum earthquake depth $(40 \mathrm{~km})$ constrains the minimum depth of deformation and the maximum temperature there (Stein, 1984). Assuming a dry olivine rheology and average global intraplate strain rate of $10^{-18} / \mathrm{s}$, the strength corresponding to a limiting temperature for seismicity of $750^{\circ} \mathrm{C}$ is 17 $\mathrm{MPa}$. As the strain rate in the Central Indian Basin is higher, possibly $10^{-15} / \mathrm{s}$, a limiting temperature for seismicity of $\sim 880^{\circ} \mathrm{C}$ may be more appropriate (Stein and Weissel, in press).

The present thermal structure was investigated by examining different models and attempting to match these three observational constraints. First, high heat flow may result from anomalous lithosphere with a basal temperature or thickness different from typical oceanic lithosphere. In this case the temperature constraints from the earthquake depths restrict the additional heat flux to less than $10-15 \mathrm{~mW} / \mathrm{m}^{2}$. Second, extra flux may result from reheating the bottom portion of the lithosphere to asthenospheric temperatures Fig.

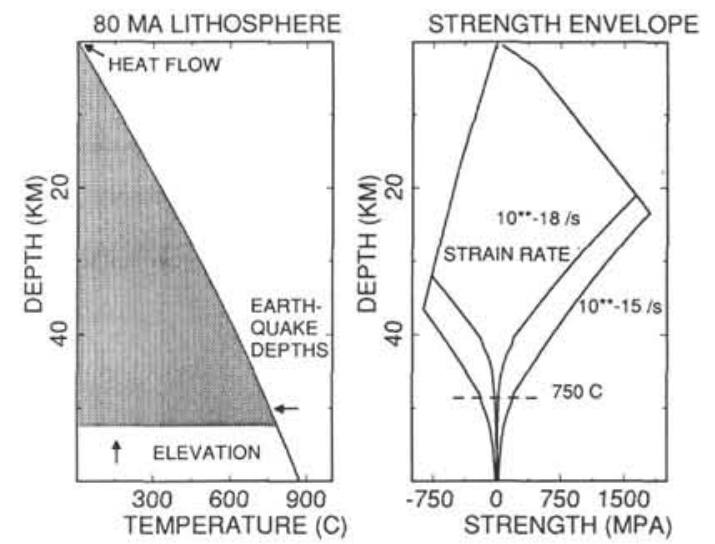

Figure 5. Geotherm and strength envelope for 80-Ma oceanic lithosphere. (Left) temperature profile for the Parsons and Sclater (1977) plate cooling model and schematic illustration of the observable constraints. Heat flow constrains the near-surface thermal gradient. The bathymetry constrains the vertical integral of the temperatures within the plate. The maximum depth of earthquakes provides information on the temperature at that depth. (Right) strength envelope calculated for a dry olivine rheology and the temperature profile shown at left. Ductile strength calculated for two strain rates of $10^{-15} / \mathrm{s}$ and $10^{-18} / \mathrm{s}$; the ductile strength is higher at greater strain rates. Zero pore pressure is assumed in brittle strength calculation. The maximum observed depth of intraplate oceanic earthquakes appears to be limited approximately by the $750^{\circ} \mathrm{C}$ isotherm (Wiens and Stein, 1983).

$8 \mathrm{~A})$. Substantial reheating $30-40 \mathrm{~km}$ below the surface is required to match the high heat flow Fig. $8 \mathrm{~B}$ ). Such reheating should produce $\sim 1 \mathrm{~km}$ of uplift, whereas the average basement depth is no shallower than expected for its age. Thus, significant deep lithospheric reheating cannot be widespread over the deformed region. Third, a temperature perturbation within the lithosphere can change the surface heat flux with time Fig. 9). A temperature perturbation at shallow depths could produce the present heat-flow anomaly, but no evidence for shallow intrusion or other mechanisms for such an effect exists. Hence, despite the heat flow anomaly, the lack of an average bathymetric anomaly and the observation of seismicity to depths in excess of $30 \mathrm{~km}$ indicate that lithospheric temperatures in the Central Indian Basin are not significantly different from those expected for its age (Stein and Weissel, in press).

It has been suggested that horizontal water flow over large distances in the Bengal Fan sediments may be responsible for the high heat flow. Drilling during Leg 116 supported the conclusions derived from temperature measurements in the upper $5 \mathrm{~m}$ (Geller et al., 1983), indicating very vigorous water flux through the sediment column and perhaps through the upper crust (Cochran, Stow, et al., 1989). This mechanism is consistent with the conclusions that the source must be shallow and that no major resetting of lithospheric temperatures has occurred (Stein and Weissel, in press).

\section{Stresses and Buckling}

If the widespread folding of sediment and acoustic basement is the result of lithospheric buckling, the stress required to produce the undulations can be estimated. Weissel et al. (1980) calculated that, to match the observed $160-\mathrm{km}$ wavelength with an elastic rheology requires stresses of $2400 \mathrm{MPa}$ $(24 \mathrm{~kb})$ and an apparent elastic thickness $(12 \mathrm{~km})$ much thinner than expected for the lithospheric age of the Central Indian Basin. Significantly lower stresses are required for other rheologies. With a depth-dependent rheology, $600 \mathrm{MPa}(6 \mathrm{~kb}$ 


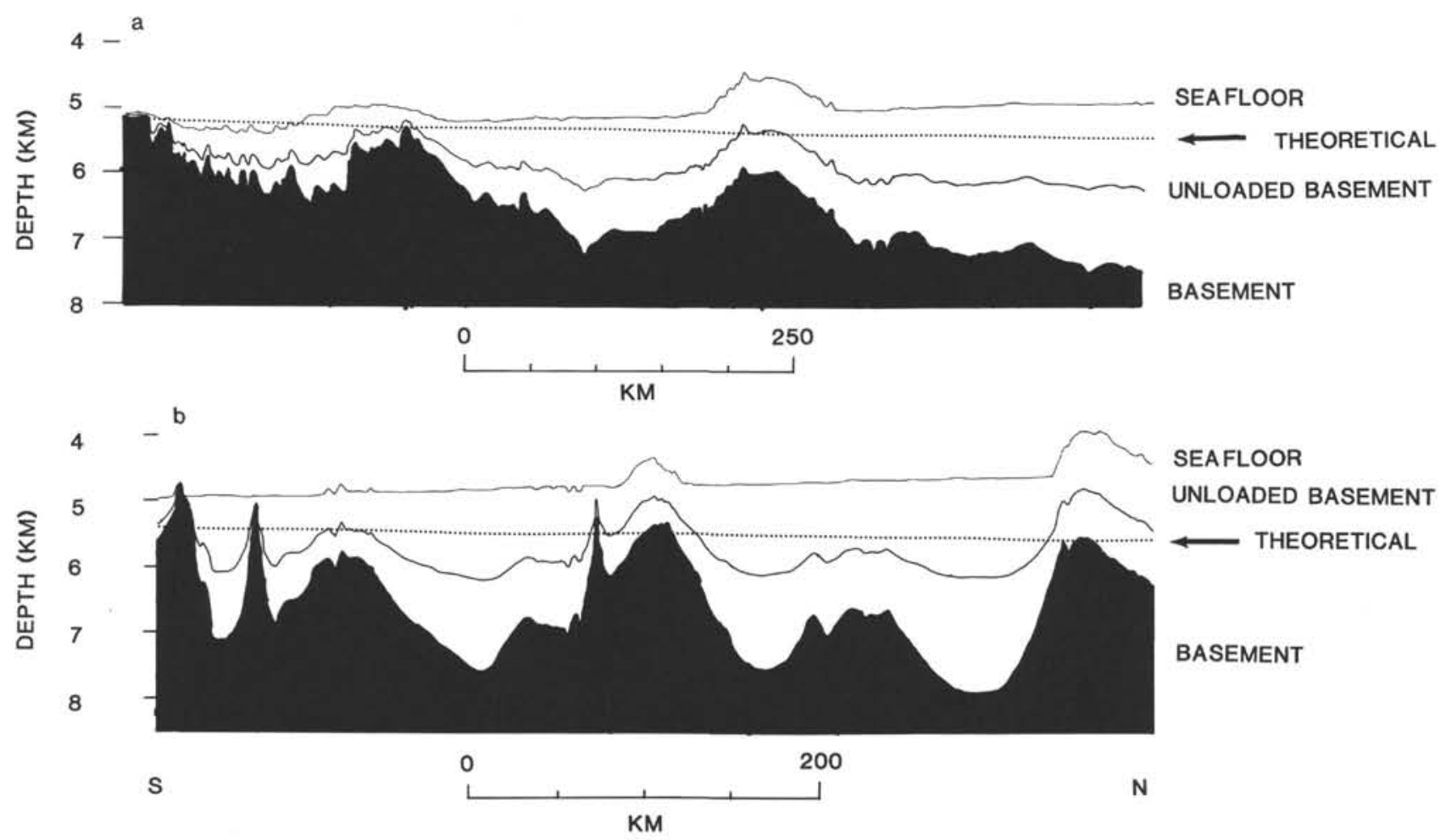

Figure 6. Depths of the seafloor, unloaded acoustic basement, and acoustic basement for the two seismic reflection profiles a and b shown in Figure 1. Profile b same as in Figure 2. Unloaded basement depths (calculated assuming Airy isostatic adjustment after "removing" sediment load) are on the average equal to or somewhat less than expected for lithospheric age (dotted line (Parsons and Sclater, 1977)). Profiles projected to $0^{\circ} \mathrm{N}$.

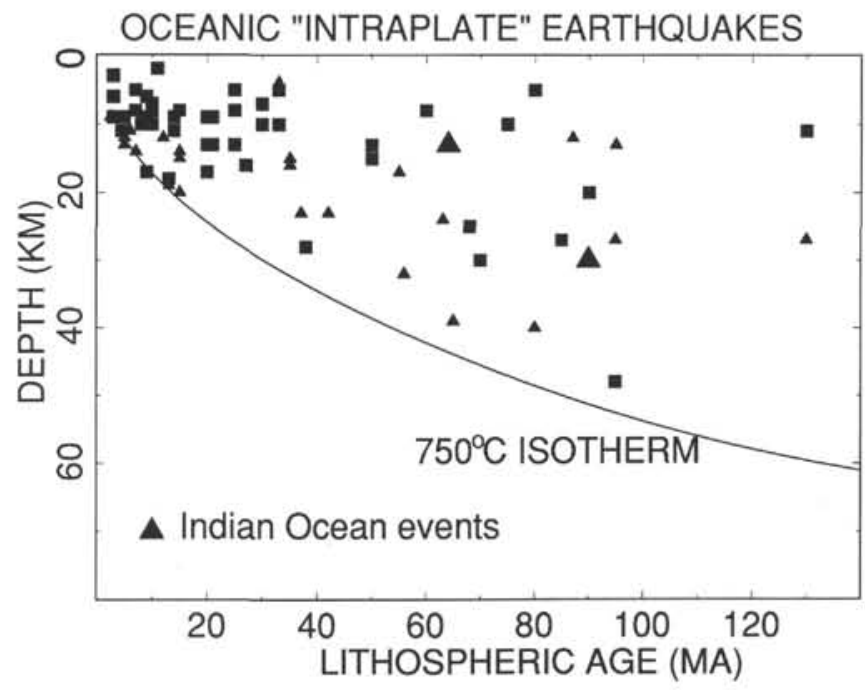

Figure 7. Focal depth vs. age for intraplate earthquakes. Those for the conventionally defined Indo-Australian Plate are shown as triangles. Larger triangles (reflecting greater uncertainty) indicate events studied using only short-period seismograph records. Data from Stein and Okal (1978), Wiens and Stein (1983, 1984), Bergman et al. (1984), Bergman and Solomon (1984, 1985), Wiens (1986), and Stein and Weissel (in press).

stresses) are required for buckling (McAdoo and Sandwell, 1985); with a viscous rheology, several hundred MPa (several kb) are required (Zuber, 1987). Analysis of seismic refraction data from the Central Indian Basin indicates that the crust beneath the fold highs may be $\sim 30 \%$ thicker compared to adjacent undeformed crust, suggesting that the hydrodynamical flow model of Zuber (1987) may be a more appropriate model of the folds than deformation by buckling (Leger, 1989). Stresses generated by plate driving forces may be able to generate stresses of these magnitudes to produce folding.

\section{Stresses and Plate Driving Forces}

If stresses resulting from plate driving forces cause the deformation in the Indian Ocean, driving force models should be able to predict the distribution of stresses inferred from earthquake locations and mechanisms and the orientation and location of fault and fold structures. Stresses for a single Indo-Australian Plate have been predicted by finiteelement modeling incorporating age-dependent slab pull and ridge push forces and basal shear forces (Cloetingh and Wortel, $1985 ; 1986)$. Figure 10 shows the calculated principal horizontal nonlithostatic stresses averaged over a uniform elastic plate with a reference thickness of $100 \mathrm{~km}$. The orientation of the stresses are consistent with those inferred from earthquake focal mechanism stadies Fig. 11). To more closely relate the calculated stresses with the magnitude of deformation we rescaled the stresses to lithosphere with an elastic thickness equal to the depth of the $750^{\circ} \mathrm{C}$ isotherm Fig. 12).

The stress orientations are compatible with the locations of well-formed grabens within the Sumatra Trench (Cloetingh and Wortel, 1986). Lateral variations in the component of the regional stress field perpendicular to the trench greatly influence the style of trench tectonics (Wortel and Cloetingh, 1985). Regional tension lowers the neutral plane in the bending plate, and promotes the development of grabens, whereas regional compression results in the opposite. Well-developed grabens within the trench are found only where the stress component normal to the trench is tensional. 
BEFORE 65-m.y. lithosphere

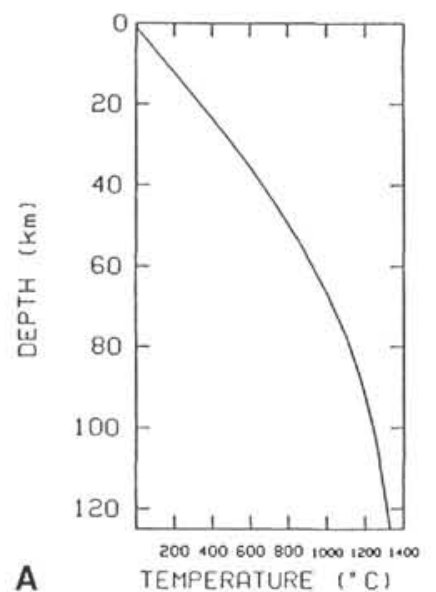

$t=0$

AFTER REHEATING

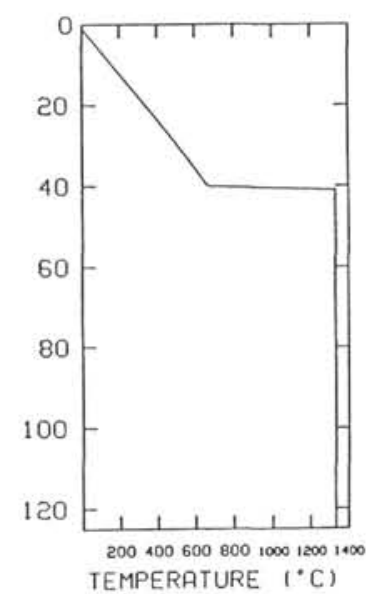

15 m.y. SINCE REHEATING

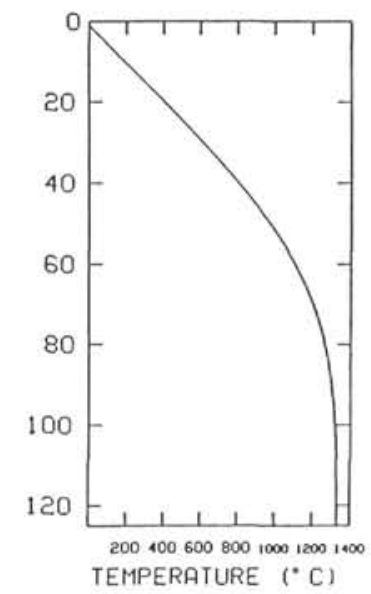

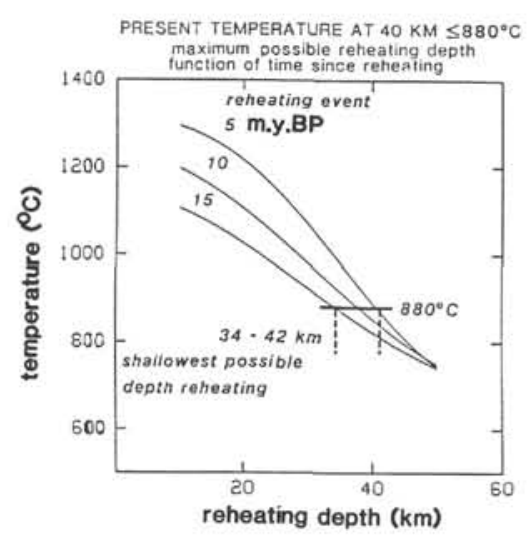

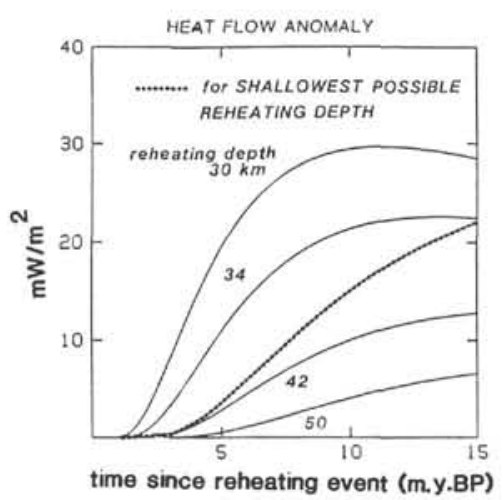

RESULTS

FROM

REHEATING

MODEL

RANGE OF POSSIBLE REHEATING DEPTHS
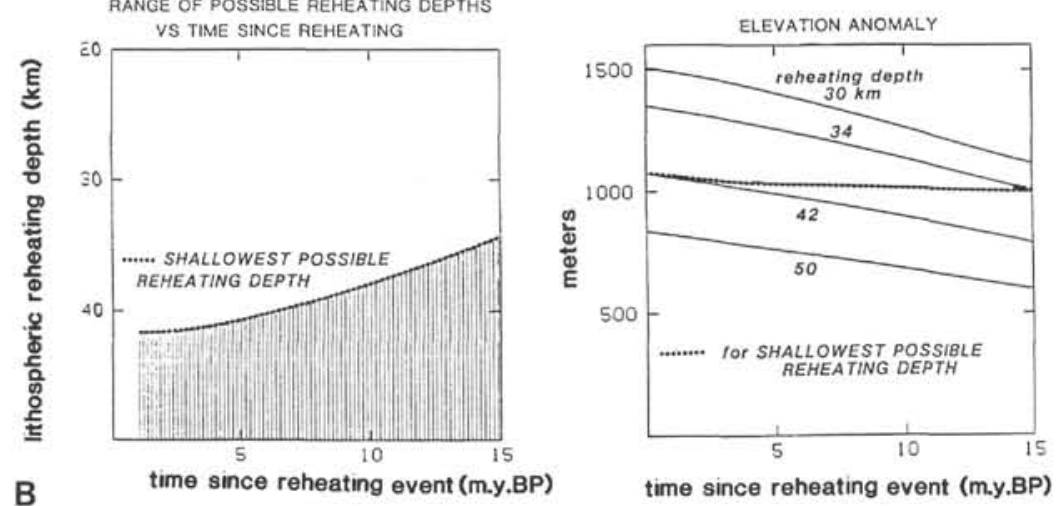

Reheating model can account for observed high heat flow but predicts large elevation anomalies.

Figure 8. A. Lithospheric basal reheating model. Excess heat flow is generated by reheating of the bottom part of the lithosphere. The temperature from the base of the lithosphere to a given depth is instantaneously reset to the basal temperature while the temperature of upper portion of the plate is unchanged. The source of the disturbance is removed and the lithosphere cools by conduction. This is illustrated for $65-\mathrm{m} . \mathrm{y}$.-old lithosphere reheated $15 \mathrm{~m} . \mathrm{y}$. BP, giving perturbed $80-\mathrm{m} . \mathrm{y}$.-old lithosphere at present. B. Lithospheric basal reheating model. (Upper left) possible combinations of time since reheating, reheating depth, and resulting temperature at $40 \mathrm{~km}$ depth. (Lower left) Shallowest possible reheating depth with time, given that the present temperature at $40 \mathrm{~km}$ should not exceed $880^{\circ} \mathrm{C}$. The longer the time since reheating, the shallower the reheating depth. An event at $1 \mathrm{Ma}$ could have reheated the lithosphere to $42 \mathrm{~km}$. An event at $15 \mathrm{Ma}$ could have reheated the lithosphere to $34 \mathrm{~km}$. (Upper right) The evolution of the surface heat flow anomaly with time since reheating is illustrated for various depths of reheating. The dotted curve illustrates the heat flow for the shallowest reheating depths consistent with the $880^{\circ} \mathrm{C}$ at $40-\mathrm{km}$ constraint (lower left). Thus a sufficiently high heat-flow anomaly can be generated with reheating to about $34 \mathrm{~km}$ while satisfying the temperature constraint. (Lower right) the evolution of the bathymetric anomaly is shown with possible reheating times and depths. The shallower the reheating depth, the greater the initial uplift. However, reheating depths sufficient to produce high heat flow yield present bathymetry almost $1 \mathrm{~km}$ shallower than observed, violating the bathymetric constraints. 


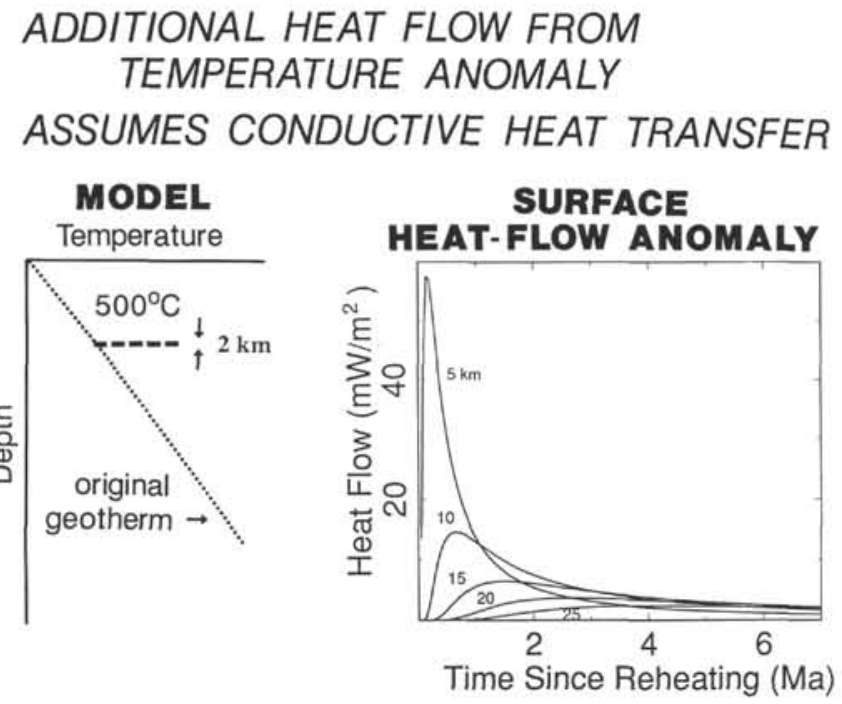

Figure 9. Shallow thermal perturbation model. The temperature of a $2-\mathrm{km}$ section of lithosphere is raised instantaneously by $500^{\circ} \mathrm{C}$. The lithosphere then cools conductively. Surface heat-flow anomaly with time since reheating is calculated for various reheating depths. To match observed heat-flow anomaly, the source must be relatively shallow and applied in the last few million years, presumably after 7 Ma when deformation began in the Central Indian Basin.

The orientation and magnitude of the calculated stresses are consistent with the present-day plate-motion model (Gordon et al., in press). The smallest predicted stresses within the diffuse plate boundary region are near the pole of Indo/ Australian relative motion (Fig. 12), where the seismicity is a minimum (Fig. 13). Within the portion of the diffuse plate boundary where the relative motions predict shortening, the stress model predicts compression, and folding and thrust faulting are observed. Similarly, where the relative motions predict extension, the stress model predicts tension, and normal faulting is observed.

If the predicted compressional stresses are large enough to produce buckling, several effects may be observable. The long-wavelength folds should be restricted to the regions of predicted compression and trend normal to the direction of maximum compression. Furthermore, the undulations extend only slightly south of the predicted transition from compression for both principal horizontal stresses to tension for one of the principal stresses. The locations of the basement undulations are shown by SEASAT gravity anomaly (Fig. 13) and seismic reflection data (Weissel et al., 1980; McAdoo and Sandwell, 1985). The spatial distribution of the folding can be mapped using SEASAT gravity anomaly data (Haxby, 1987). Due to the thick sediments of the Bengal Fan, partially deposited after the initiation of deformation in the Central Indian Ocean, the northern undulations cannot often be identified using bathymetric data. In the Central Indian Basin, undulations trending east-west are best developed from about $3^{\circ} \mathrm{N}$ to $10^{\circ} \mathrm{S}$ and $80^{\circ} \mathrm{E}$ to $85^{\circ} \mathrm{E}$ (Fig. 14), but continue to the west and east into the Wharton Basin. Although the northernmost observed sediment deformation is just south of DSDP Site $118\left(8^{\circ} \mathrm{N}, 86^{\circ} \mathrm{E}\right)$ (J. Curray, pers. comm., 1988), some deformation may extend somewhat northward as seismicity continues to the north. In the Wharton Basin, NE-SW trending undulations can be most clearly seen from $6^{\circ} \mathrm{S}$ to $18^{\circ} \mathrm{S}$ (Fig. $15)$. North of $6^{\circ} \mathrm{S}$ they are difficult to distinguish from abandoned spreading centers, fracture zones (Liu et al., 1983) and the trench outer high. The locations and orientations of the basement undulations are remarkably consistent with the predicted stresses (Stein et al., 1989).
Folding in the Indian Ocean appears to result from the plate-wide stress distribution. On the local scale, pre-existing loads may affect the deflections (Lambeck, 1983a, 1983b) resulting from compressional stresses. Karner and Weissel (this volume) suggest that the Afanasiy Nikitin seamounts have affected the pattern of folding in the Central Indian Basin in such a manner and may be the reason why folds near these seamounts are so prominent.

\section{OTHER MORPHOLOGIC FEATURES}

Examination of the deformation reflected in the gravity data (Haxby, 1987) has interesting implications for three prominent features of the northeastern Indian Ocean: the Ninetyeast, $85^{\circ} \mathrm{E}$, and the southern Chagos-Laccadive Ridges. The morphology of the Ninetyeast Ridge changes from a smooth continuous ridge south of $7^{\circ}-10^{\circ} \mathrm{S}$ to a series of en echelon ENE-WSW-trending highs north of $7^{\circ}-10^{\circ} \mathrm{S}$ (Sclater and Fisher, 1974). This difference is puzzling because the ridge is thought to be a hot-spot track reflecting the rapid northward motion of India (Morgan, 1972; Peirce, 1978). Sclater and Fisher (1974) suggested that the change in ridge morphology may reflect the separation of Australia and Antarctica. Stein and Okal (1978) noted that the irregular morphology is associated with the region of highest seismicity.

The gravity anomaly data (Fig. 14) shows that the highs on the Ninetyeast Ridge are located at about the same latitude and have a spacing similar to undulations to the west in the Central Indian Basin (Stein et al., 1989). The bathymetric data show that the depths between the highs and lows on the Ninetyeast Ridge are sometimes equal or greater than $1 \mathrm{~km}$, similar to the maximum fold amplitudes in the Central Indian and Wharton Basins. Stein et al. (1989) proposed that the morphology of the northern Ninetyeast Ridge is a continuation of the basement undulations from the west and hence reflects the recent deformation that has modified the original smooth morphology, presently preserved to the south. Comparison with the stress model thus suggests that the ENEWSW trend of the en echelon highs may reflect the predicted variation in stress from north-south compression west of the northern Ninetyeast Ridge to NW-SE compression east of the Ridge. Similarly, the smooth morphology occurs where the model does not predict large compressional stresses. Petroy and Wiens (1989) also suggest that the morphology of the northern Ninetyeast Ridge reflects the recent lithospheric buckling. Such models hence explain the correlation of seismicity, gravity, and ridge morphology.

Using shipboard gravity and seismic reflection data, Liu et al. (1982) identified the buried $85^{\circ} \mathrm{E}$ Ridge that extends from $\sim 18^{\circ} \mathrm{N}$ to $\sim 5^{\circ} \mathrm{N}$ and characterized by a free-air gravity low. Although the ridge approximately parallels the Ninetyeast Ridge north of $5^{\circ} \mathrm{N}$, Liu et al. interpreted its trend as diverging to the southwest from $3^{\circ} \mathrm{N}$ to $5^{\circ} \mathrm{N}$, and noted that this change precluded a hot-spot origin unless the hot spot moved relative to that presumably forming the Ninetyeast Ridge. At $\sim 5^{\circ} \mathrm{N}$, where Liu et al. (1982) show the trend of the $85^{\circ} \mathrm{E}$ Ridge changing to the southwest, the SEASAT gravity data show a gravity low continuing to the south. Liu et al. (1982) had a gap in the shipboard gravity data for the region between $\sim 1^{\circ} \mathrm{N}-5^{\circ} \mathrm{N}$ and $\sim 85^{\circ} \mathrm{E}-87^{\circ} \mathrm{E}$. Hence, the $85^{\circ} \mathrm{E}$ Ridge may continue to the south and an undulation high at $3^{\circ} \mathrm{N}$, south of Sri Lanka, previously interpreted as the southern portion of the $85^{\circ} \mathrm{E}$ Ridge, may instead reflect the recent deformation (Stein et al., 1989).

The maximum predicted tensional stresses are located (Fig. 13) near the southern portion of the Chagos Laccadive Ridge (Stein et al., 1987), an area associated with large normal fault earthquakes and rapid recent subsidence. The ridge was produced as the Indo-Australian Plate moved over a hot spot (Morgan, 1972; Duncan, 1981). Associated magmatic activity is located from the Deccan traps to Reunion lsland. The 


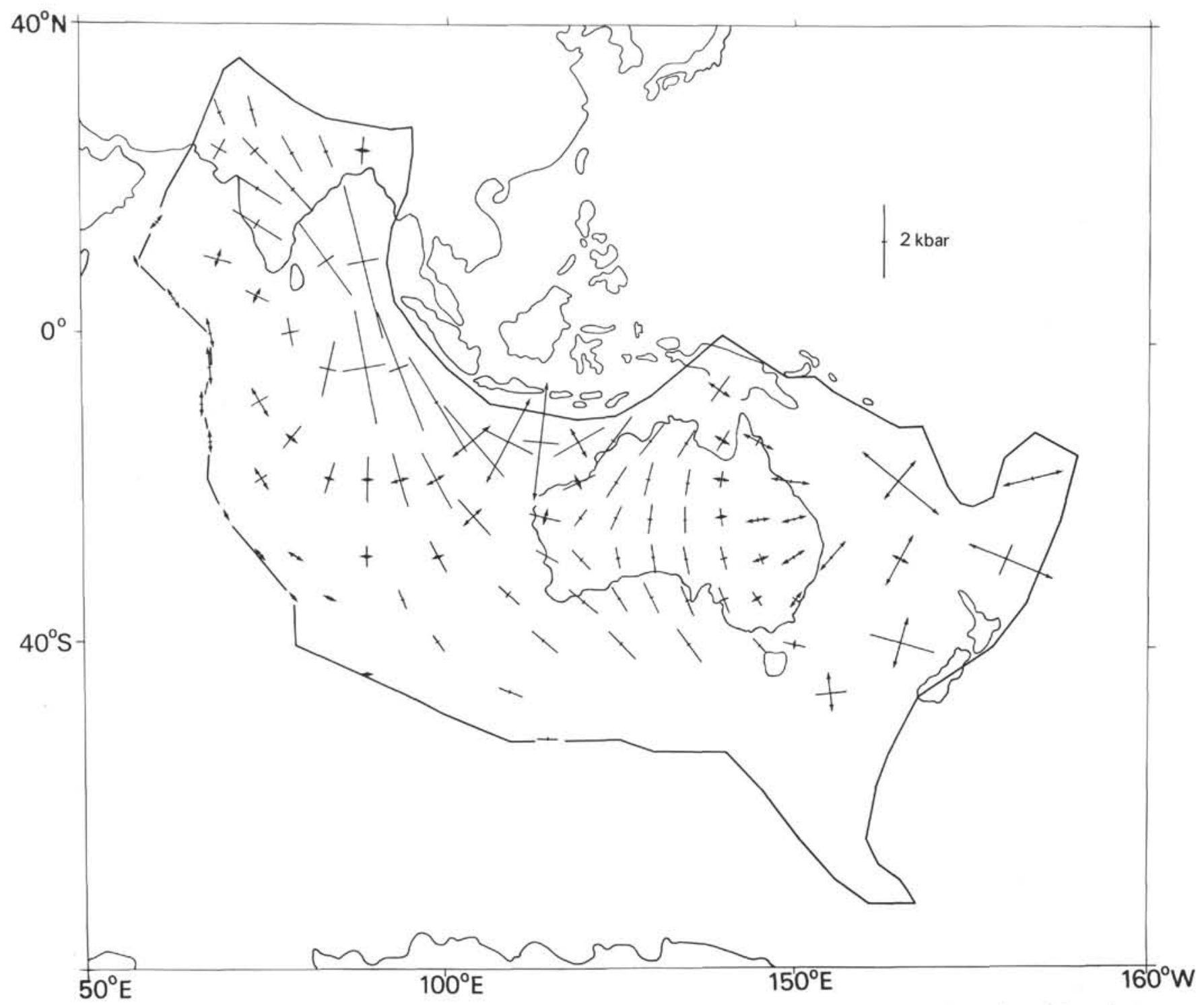

Figure 10. Regional stress field in the Indo-Australian Plate (Cloetingh and Wortel, 1985, 1986). The principal horizontal nonlithostatic stresses averaged over a uniform elastic plate with a reference thickness of $100 \mathrm{~km}$ are plotted. Lines with outward-pointing arrows indicate tensional stresses and those without arrows indicate compressional stresses. The magnitude of the stress is represented by the total length (from end to end) of each bar.

volcanic edifice was formed near sea level and subsequently covered with carbonate reefs, although the subsidence of the crystalline crust appears to be that expected for oceanic seafloor of its age (Detrick et al., 1977). Some portions of the coral reef complex have recently undergone very rapid subsidence and drowning (Darwin, 1842; Schlanger and Stein, 1987). Major differences in subsidence rates within a small region should not occur because the height of the ridge should be a function of the slow thermal cooling of the ocean seafloor and the growth of the reef complexes. However, the seismicity within the extensional region near the Chagos-Laccadive Ridge occurs (Fig. 16) on local gravity minima and bathymetric lows south and west of the Chagos Bank $\left(6^{\circ} \mathrm{S}, 72^{\circ} \mathrm{E}\right)$. The deeps between the shallower portions strike either approximately N-S to NNE-SSW, in accord with the nodal planes of the two normal faulting earthquakes. To the west, between the Chagos-Laccadive Ridge and the spreading ridges, strike-slip earthquakes occur near the expected fracture zone locations. This orientation of lows and nodal planes are those expected from the stress modeling (Cloetingh and Wortel, 1985; 1986).

\section{SEISMICITY}

We examined possible relations between the seismicity, gravity, and predicted stresses (Cloetingh and Wortel, 1985; 1986). Focal mechanism types (Fig. 12) vary from strike slip and thrust east of $\sim 75^{\circ} \mathrm{E}$, to extension and strike slip near the Chagos-Laccadive Ridge. This variation is consistent with the displacements predicted by the diffuse plate boundary model (Wiens et al., 1985), because the change from extension to convergence should occur within the boundary zone at the location of the Australia-India relative motion pole. It is intriguing to note that the predicted change from compressional to tensional stresses also agrees with the focal mechanism solutions and the diffuse plate boundary model.

Given that the undulations and seismicity presumably both reflect the diffuse boundary deformation, it is interesting that the epicenters in the compressional region are not preferentially located with respect to the peaks and troughs of the undulations Figs. 17 and 18). Moreover, the strike-slip earthquakes occur on all parts of the undulations, although the 


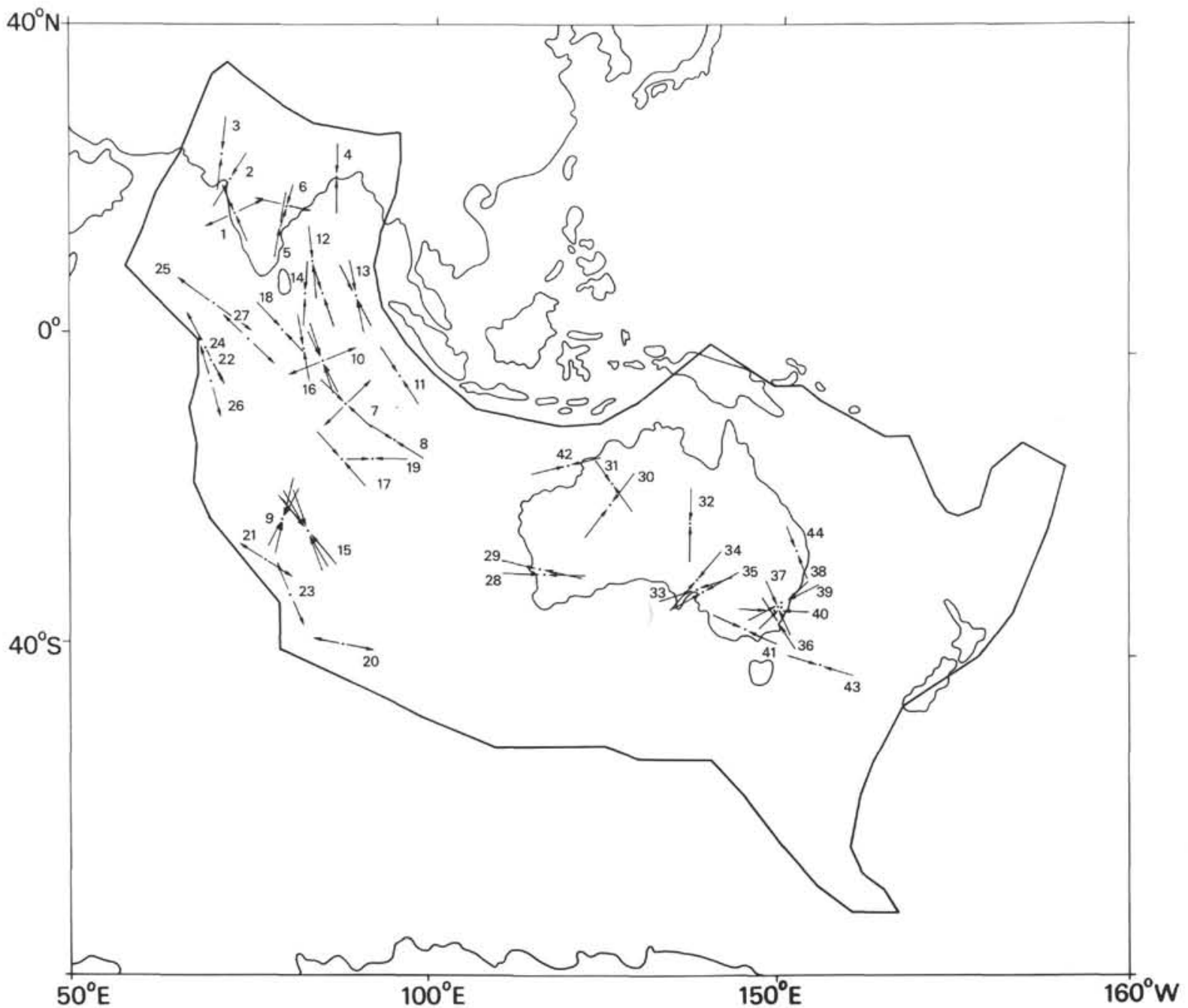

Figure 11. Compilation of intraplate focal mechanism stress orientation data for the Indo-Australian Plate (Cloetingh and Wortel, 1986). Numbers correspond to the event numbers in Table 1 Cloetingh and Wortel (1986).

epicenters are often near fracture zones. However, because the undulations are not visibly offset near the strike-slip earthquakes or at the fracture zones, the net horizontal displacement has probably not been large. Petroy and Wiens (1989) suggest that the large earthquakes associated with the Ninetyeast Ridge occur not on the eastern side where a major fracture zone has been inferred, but on the west side where no fracture zone has been inferred.

\section{DISCUSSION}

The sign, direction, and magnitude of the stresses predicted by the numerical model (Cloetingh and Wortel, 1985, 1986) agree well with the gravity and seismicity observations and the motion predicted by the diffuse plate boundary model (Fig. 19). Thus the combined results of kinematic and dynamic models lead to a consistent picture: the high stresses predicted by the dynamic model of the single Indo-Australian Plate account for the location and the nature of the diffuse plate boundary as derived from kinematics. The idea that the deformation results from plate-wide stresses is consistent with the deformations not being associated with major resetting of temperatures throughout the entire lithosphere (Stein and Weissel, in press).

The magnitudes of the predicted stresses are not easily tested. These stresses are comparable to those inferred from the wavelengths of the folding (McAdoo and Sandwell, 1985; Zuber, 1987) (Fig. 19) and from the depth distribution of seismicity. Similar stresses can also be inferred from the depth of seismicity, which often occurs at depths where the lithosphere should have considerable strength (Wiens and Stein, 1983; Stein, 1984). If faulting requires that the ambient stress equal or exceed the strength expected on rheological grounds, the focal depths imply stresses in good agreement with those predicted implies stresses are in agreement with those predicted (Wortel, Govers, Cloetingh, and Stein, unpublished data). Richardson (1987) has shown that assumptions of the boundary forces for the collisional zones are critical in determining the overall level of stresses, and offered a model with significantly lower stresses.

It may be possible to obtain an additional constraint on the magnitude of the predicted stresses. Apparent sea level at continental margins may be affected by intraplate stresses (Cloetingh et al., 1985; Cloetingh, 1986; Karner, 1986). A relative sea-level change of $\sim 50 \mathrm{~m}$ at passive continental margins with distinct onlap/offlap patterns should occur from a $\sim 50 \mathrm{MPa}$ stress change (Cloetingh et al., 1989). Thus, apparent sea-level changes along the Indian and northwestern Australian margins should have occurred, given the high predicted stresses (Stein et al., 1989). Unfortunately, little information has been published in a format useful for analysis 


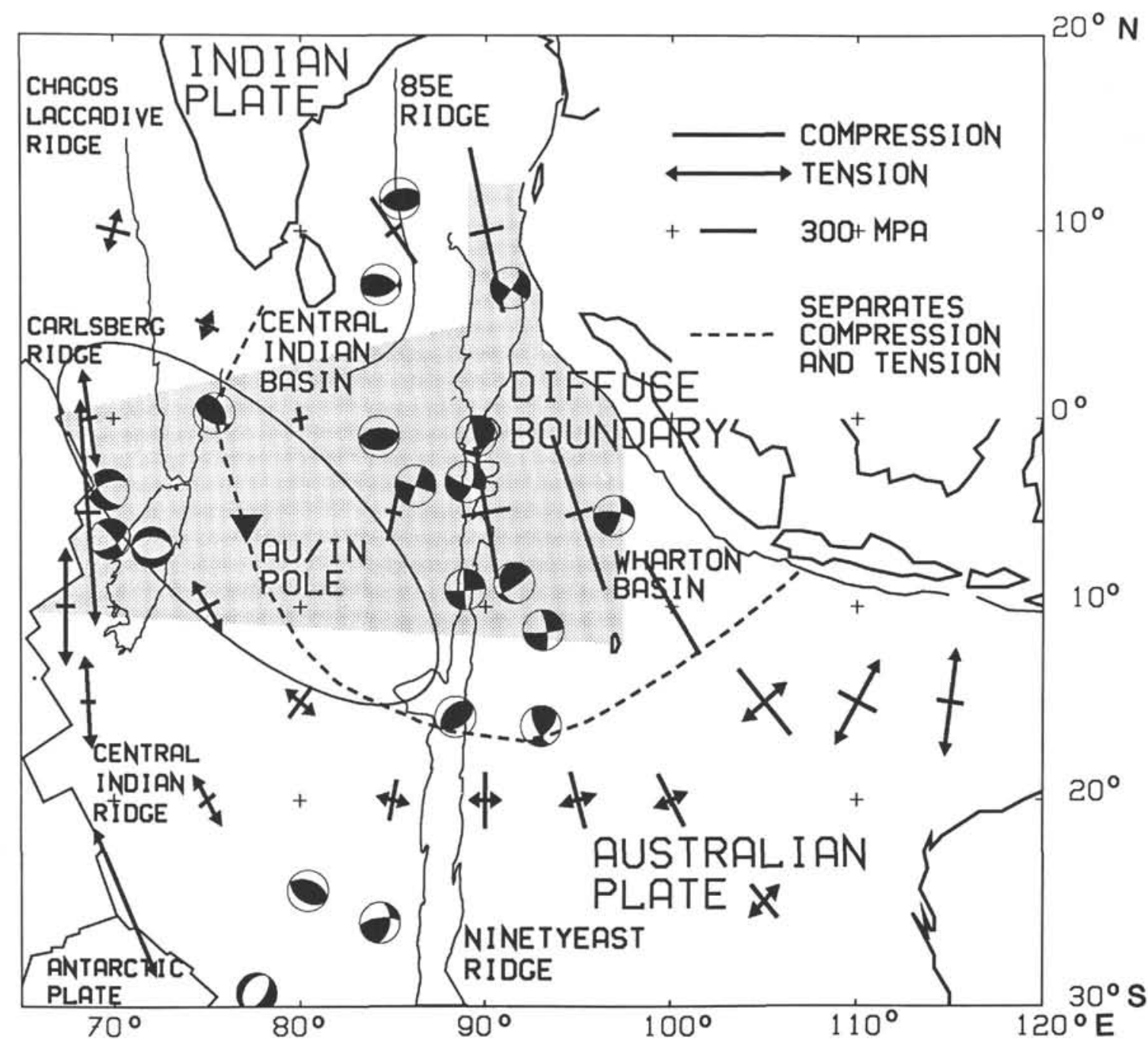

Figure 12. Plate geometry, predicted stress field, and "intraplate" focal mechanisms for the Indian Ocean. AustraliaIndian Euler pole location from Gordon et al. (in press); diffuse Indo-Australian boundary shaded; principal horizontal nonlithostatic stresses (Cloetingh and Wortel, 1985) are vertically averaged for an elastic plate thickness corresponding to the $750^{\circ} \mathrm{C}$ isotherm. The dashed line separates the region with both compressional horizontal principal stresses from that with tensional and compressional ones. The transition from compression to tension south of the Sunda Trench results from the subduction of older oceanic lithosphere in the eastern portion. Focal mechanisms are from Stein (1978), Wiens and Stein (1984), Bergman et al. (1984), Bergman and Solomon (1984, 1985), Wiens (1986), Stein and Weissel (in press), and Petroy and Wiens (1989). (From Stein et al., 1989).

and the Indian sea-level studies are complicated by the effects of the Himalayan uplift and fan deposition. Pandey (1986) suggests the east Indian shelf experienced major uplift and regression about $12 \mathrm{Ma}$. Given that the stress change required to produce significant relative sea-level changes at passive margins is an order of magnitude less than that required to buckle the Indian Ocean lithosphere, if the stress slowly increased with time the continental margins might record the stress changes prior to the $\sim 7.5 \mathrm{Ma}$ (Cochran, this volume) onset of the deformation.

The bathymetric highs and lows on seismic reflection records (Geller et al., 1983) correlate well with the undulations in the Central Indian Basin from gravity data. The width of the bathymetric and gravity highs vary along individual undulations. This variation may, in part, be due to the nature of the seafloor prior to folding. Some of the ocean floor within the diffuse plate boundary was affected by a massive outpouring of magma on very young lithosphere in Late Cretaceous time.
The Afanasiy-Nikitin seamounts in the Central Indian Basin, which occur along a fracture zone at about $3^{\circ} \mathrm{S}, 83^{\circ} \mathrm{E}$, record this event. This magmatism is more clearly shown on the less-sedimented Antarctic Plate by the contemporaneous seamounts extending from the $\mathrm{Ob}$ seamount $\left(52^{\circ} \mathrm{S}, 41^{\circ} \mathrm{E}\right)$ to the easternmost Marion Dufresne Seamount $\left(54^{\circ} \mathrm{S}, 52^{\circ} \mathrm{E}\right)$ (Goslin and Schlich, 1982). The Central Indian Basin seamounts do not exactly mirror those on the Antarctic Plate, as the Central Indian Basin ones (except the northern portion of the Afanasiy-Nikitin seamounts) are much deeper than those on the Antarctic Plate. Either the height of the seamounts have been affected by the deformation, or they were formed at a deeper depth.

\section{CONCLUSIONS}

The combined results of kinematic and dynamic analyses of the northern Indian Ocean explain the concentration of tectonic activity as inferred from seismicity, gravity, and 


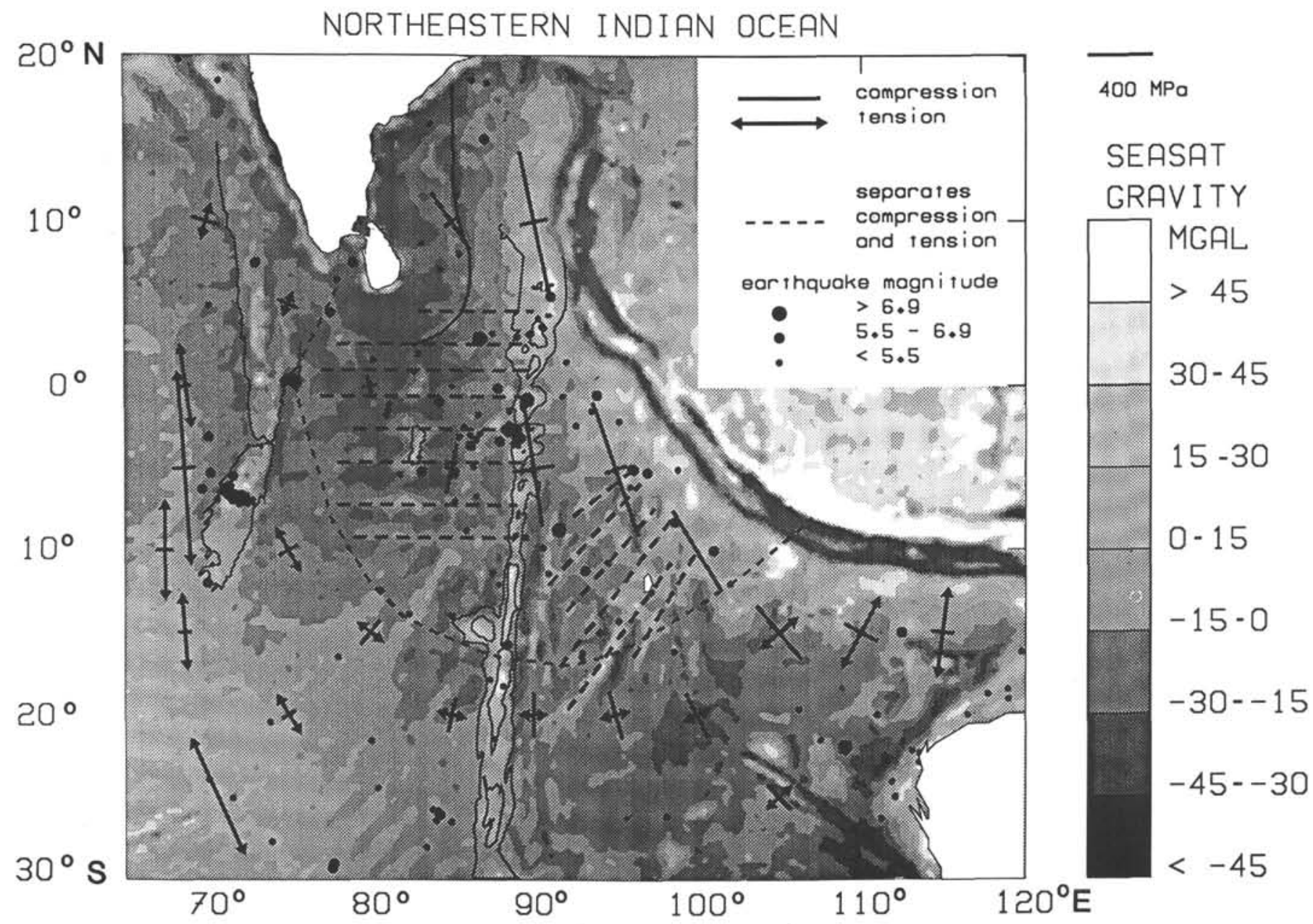

Figure 13. "Intraplate" earthquakes, gravity anomalies (Haxby, 1987), and predicted stresses Fig. 12). Note that the orientation of the gravity highs corresponding to the buckled oceanic lithosphere agrees with the orientation predicted by the compressional stress field. The undulations are not observed far south of the predicted transition from compressional to tensional stresses. The undulation patterns at $3^{\circ} \mathrm{S}, 83^{\circ} \mathrm{E}$ are distorted by the Afanasiy Nikitin seamounts. The Chagos-Laccadive Ridge is shown by the $3.5-\mathrm{km}$ contour. The seamounts and Ninetyeast Ridge are shown by the $2.5-$ and $4.0-\mathrm{km}$ contours. Solid line gives the trend of the $85^{\circ} \mathrm{E}$ Ridge given by Liu et al. (1982). (From Stein et al., 1989).

marine geophysical data. The kinematic analysis has resulted in the definition of a diffuse plate boundary between the Indian and Australian Plates. The characteristics of lithospheric stress fields (magnitude and orientation) predicted by a quantitative dynamic model adopting the boundaries of the IndoAustralian Plate accounts for the observed location and nature of the diffuse plate boundary zone.

\section{ACKNOWLEDGMENTS}

This research was supported by grants from the Petroleum Research Fund, administered by the American Chemical Society, NATO Grant $0148 / 87$, and the American Philosophical Society. The first author thanks the Department of Theoretical Geophysics, University of Utrecht, for their hospitality during the early stages of this research. We also thank D. Petroy and D. Wiens for their preprint. We thank J. Curray for a map of the Wharton seafloor fabric and discussion about the $85^{\circ} \mathrm{E}$ Ridge.

\section{REFERENCES}

Anderson, R. N., Langseth, M. G., and Sclater J. G., 1977. Mechanisms of heat transfer through the floor of the Indian Ocean. $J$. Geophys. Res., 82:3391-3409.
Bergman, E. A., Nabelek, J. L., and Solomon, S. C., 1984. An extensive region of off-ridge normal-faulting earthquakes in the Southern Indian Ocean. J. Geophys. Res., 89:2425-2443.

Bergman, E. A., and Solomon, S. C., 1984. Source mechanisms of earthquakes near mid-ocean ridges from body waveform inversion: Implications for the early evolution of oceanic lithosphere. $J$. Geophys. Res., 89:11,415-11,441.

1985. Earthquake source mechanisms from body-waveform inversion and intraplate tectonics in the northern Indian Ocean. Phys. Earth Planet. Int., 40:1-23.

Chen, W. P., and Molnar, P., 1983. Focal depths of intracontinental and intraplate earthquakes and their implications for the thermal and mechanical properties of the lithosphere. J. Geophys. Res., $88: 4183-4214$.

Cloetingh, S., 1986. Intraplate stresses: A new tectonic mechanism for regional sealevel variations. Geology, 14:617-621.

Cloetingh, S., Kooi, H., and Groenewoud, W., 1989. Intraplate stresses and sedimentary basin evolution. Proc., IUGG Symp. Sedimentary Basins: Washington (Am. Geophys. Union), 1-18.

Cloetingh, S., McQueen, H., and Immbeck, K., 1985. On a tectonic mechanism for regional sealevel variations. Earth Planet. Sci. Lett., 75:157-166.

Cloetingh, S. and Wortel, R., 1985. Regional stress field of the Indian Plate. Geophys. Res., Lett., 12:77-80.

1986. Stress in the Indo-Australian Plate. Tectonophysics, 132:49-67. 
Cochran, J. R., and Talwani, M., 1977. Free-air gravity anomalies in the world's oceans and their relationship to residual elevations. Geophys. J. R. Astron. Soc., 50:495-552.

Curray, J. R., and Moore, D. G., 1971. Growth of the Bengal DeepSea Fan and denudation in the Himalayas. Geol. Soc. Am. Bull., $82: 563-572$.

Curray, J. R., and Munasinghe, T., 1989. Timing of intraplate deformation, northeastern Indian Ocean. Earth Planet. Sci. Lett., 84:71-77.

Darwin, C., 1842. The Voyage of the Beagle: Tucson (University of Arizona Press, republished).

DeMets, C., Gordon, R. G., and Argus, D., 1988. Intraplate deformation and closure of the Australian-Antarctic-Africa plate circuit. $J$. Geophys. Res., 93: 11,877-11,897.

DeMets, C., Gordon, R. G., Argus, D., Stein, S., in press. Current plate motions. Geophys. J. R. Astron. Soc.

Detrick, R. S., Sclater, J. G., and Thiede, J., 1977. The subsidence of aseismic ridges. Earth Planet. Sci. Lett., 134:185-196.

Duncan, R. A., 1981. Hotspots in the southern oceans-an absolute frame of reference for motion of the Gondwana continents. Tectonophysics, 74:29-42.

Eittreim, S. L., and Ewing, J., 1972. Midplate tectonics in the Indian Ocean. J. Geophys. Res., 77:6413-6421.

Fitch, T. J., 1972. Plate convergence, transcurrent faults and the internal deformation adjacent to Southeast Asia and the western Pacific. J. Geophys. Res., 77:4432-4460.

Geller, C. A., Weissel, J. K., and Anderson, R. N., 1983. Heat transfer and intraplate deformation in the central Indian Ocean. $J$. Geophys. Res., 88:1018-1032.

Goetze, C., 1978. The mechanisms of creep in olivine. Phil. Trans. Roy. Soc. London, Ser. A., 288:99-119.

Goetze, C., and Evans, B., 1979. Stress and temperature in the bending lithosphere as constrained by experimental rock mechanics. Geophys. J. R. Astron. Soc., 59:463-478.

Gordon, R. G., DeMets, C., and Argus, D. F., in press. Present-day motion between the Australian and Indian Plates: kinematic constraints on the distributed lithospheric deformation in the equatorial Indian Ocean. Tectonics.

Goslin, J., and Schlich, R., 1982. Structural limits of the Southern Crozet Basin relations to Enderby Basin and the Kerguelen-Heard Plateau. In Craddock, C. (Ed.), Antarctic Geoscience, IUGS B4, 79-85.

Gutenberg, B., and Richter, C. F., 1954. Seismicity of the Earth: Princeton, N.J. (Princeton University Press).

Haxby, W., 1987. Gravity Field of the World's Oceans: Boulder (National Geophysical Data Center).

Karner, G. D., 1986. Effects of lithospheric in-plane stress on sedimentary basin stratigraphy. Tectonics, 5:573-588.

Lambeck, K., 1983a. Structure and evolution of the intracratonic basins of central Australia. Geophys. J. R. Astron. Soc., 74:843-886. $1983 \mathrm{~b}$. The role of compressive forces in intracratonic basin formation and mid-plate orogenies. Geophys. Res. Lett., 10:845848 .

Lawver, L. A., and Taylor, P. T., 1987. Heat flow off Sumatra. Marine Physical Lab. Rep. No. MPL-U-42/87:67-76.

Leger, G. T., 1989. Was the oceanic crust in the Central Indian Basin deformed by lithospheric boudinage? evidence from seismic refraction. [MS. thesis], Dalhousie University, Halifax, Canada.

Liu, C.-S., Curray, J. R., and McDonald, J. M., 1983. New constraints on the tectonic evolution of the eastern Indian Ocean. Earth Planet. Sci. Lett., 65:331-342.

Liu, C.-S., Sandwell, D. T., and Curray, J. R., 1982. The negative gravity field over the $85^{\circ} \mathrm{E}$ Ridge. J. Geophys. Res., 87:7673-7686.

McAdoo, D. C., and Sandwell, D. T., 1985. Folding of oceanic lithosphere. J. Geophys. Res., 90:8563-8569.

Minster, J. B., and Jordan, T. H., 1978. Present-day plate motions. J. Geophys. Res., 83:5331-5354.

Moore, D. G., Curray, J. R., Raitt, R. W., and Emmel, F. J., 1974. Stratigraphic-seismic section correlations and implications to Bengal Fan history. In Heezen, B. C., MacGregor, I. D., et al., Init. Repts. DSDP, 22:403-412.

Morgan, W. J., 1972. Plate motions and deep mantle convection. In Shagam, R. et al. (Eds), Studies in Earth and Space Sciences (Hess volume). Geol. Soc. Am. Mem., 132:7-22.
Neprochnov, Y. P., Levchenko, O. V., Merklin, L. R., and V. V. Sedov, 1988. The structure and tectonics of the intraplate deformation area in the Indian Ocean. Tectonophysics, 156:89-106.

ODP Leg 116 Shipboard Scientific Party, 1987. Ocean Drilling Program, collisions in the Indian Ocean. Nature, 1330:519-521.

Pandey, J., 1986. Some recent paleontological stadies and their implications on the Cenozoic stratigraphy of Indian subcontinent. ONGC Bull., 23:1-44.

Parsons, B., and Sclater, J. G., 1977. An analysis of the variation of ocean floor bathymetry and heat flow with age. J. Geophys. Res., 82:803-827.

Peirce, J. W., 1978. The northward motion of India since the Late Cretaceous. Geophys. J. R. Astron. Soc., 52:277-311.

Petroy, D. E., and Wiens, D. A., 1989. Historical seismicity and implications for diffuse plate convergence in the northeast Indian Ocean. J. Geophys. Res., 94:12,301-12,319.

Richardson, R. M., 1987. Modeling the tectonics of the Indo-Australian Plate. Eos, 68:1466.

Richardson, R. M., Solomon, S. C., and Sleep, N. H., 1979. Tectonic stress in the plates. Rev. Geophys. Space Phys., 17:981-1019.

Rothe, J. P., 1969. Seismicity of the Earth. Paris (UNESCO). Schlanger, S. O., and Stein, S. A., 1987. Charles Darwin and Captain Moresby on the drowning of the Great Chagos Bank: 19th Century discovery of "aseismic" ridge seismicity in the Indian Ocean. Eos, 68:140-141.

Sclater, J. G., and Fisher, R. L., 1974. The evolution of the east central Indian Ocean, with emphasis on the tectonic setting of the Ninetyeast Ridge. Geol. Soc. Am. Bull., 85:683-702.

Shcherbakov, V. S., et al., 1989. A study of intraplate deformations by seismic methods in the Indian Ocean. All-Union Conference, Plate tectonics and related mineral deposits, Oct. 25-27, 1989. Moscow, U.S.S.R. Abstract Vol. 11.

Stein, C. A., 1984. Part I-Heat transfer, seismicity, and intraplate deformation in the central Indian Ocean. Part II-The transition between the Sheba Ridge and the Owen Basin: Rifting of old oceanic lithosphere. [Ph.D. thesis], Columbia University, New York.

Stein, C. A., Cloetingh, S., and Wortel, R., 1989. Seasat-derived gravity constraints on stress and deformation in the northeastern Indian Ocean. Geophys. Res. Lett., 16:823-826.

Stein, C. A., Hobart, M. A., and Abbott, D. H., 1988. Has the Wharton Basin's heat flow been perturbed by the formation of a diffuse plate boundary in the Indian Ocean? Geophys. Res. Lett., 15:455-458.

Stein, C. A., and Weissel, J. K., in press. Constraints on Central Indian Basin thermal structure from heat flow, seismicity, and bathymetry. Tectonophysics.

Stein, S., 1978. An earthquake swarm on the Chagos-Laccadive Ridge and its tectonic implications. Geophys. J. R. Astron. Soc., 55:577588.

Stein, S., Cloetingh, S., Wiens, D. A., and Wortel, R., 1987. Why does near ridge extensional seismicity occur primarily in the Indian Ocean? Earth Planet. Sci. Lett., 82:107-113.

Stein, S., and Gordon, R. G., 1984. Statistical tests of additional plate boundaries from plate motion inversions. Earth Planet. Sci. Lett., 69:401-412.

Stein, S. and E. A. Okal, 1978. Seismicity and tectonics of the Ninetyeast Ridge area: evidence for internal deformation of the Indian Plate. J. Geophys. Res., 83:2233-2246.

Stover, C. W., 1966. Seismicity of the Indian Ocean. J. Geophys. Res., 71:2575-2581.

Sykes, L. R., 1970. Seismicity of the Indian Ocean and a possible nascent island arc between Ceylon and Australia. J. Geophys. Res., 75:5041-5055.

Von Herzen, R. P., Detrick, R. S., Crough, S. T., Epp, D., and Fehn, U., 1982. Thermal origin of the Hawaiian swell: heat flow evidence and thermal models. J. Geophys. Res., 87:6711-6723.

Weissel, J. K., Anderson, R. N., and Geller, C. A., 1980. Deformation of the Indo-Australian Plate. Nature, 287:284-291.

Wiens, D. A., 1986. Historical seismicity near Chagos: A complex deformation zone in the equatorial Indian Ocean. Earth Planet. Sci. Lett., 76:350-360.

Wiens, D. A., DeMets, C., Gordon, R. G., Stein, S., Argus, D., Engeln, J. F., Lundgren, P., Quible, D., Stein, C., Weinstein, S. 
and Woods, D. F., 1985. A diffuse plate boundary model for Indian Ocean tectonics. Geophys. Res. Lett., 12:429-432.

Wiens, D. A., and Stein, S., 1983. Age dependence of oceanic intraplate seismicity and implications for lithospheric evolution. $J$. Geophys. Res., 88:6455-6668.

1984. Intraplate seismicity and stresses in young oceanic lithosphere. J. Geophys. Res., 89:11,442-11,464.

Wiens, D., Stein, S., DeMets, C., Gordon, R., and Stein, C., 1986. Plate tectonic models for Indian Ocean "intraplate" deformation. Tectonophysics, 132: 37-48.

Wilson, J. T., 1965. A new class of faults and their bearing on continental drift. Nature, 207:343-347.
Wortel, M.J.R., and Cloetingh, S.A.P.L., 1985. Accretion and lateral variations in tectonic structure along the Peru-Chile trench. Tectonophysics, 112:443-462.

Zuber, M. T., 1987. Compression of oceanic lithosphere: An analysis of intraplate deformation in the central Indian Basin. J. Geophys. Res., 92:4817-4825.

Date of initial receipt: 11 May 1989

Date of acceptance: 6 February 1990

Ms 116B-153

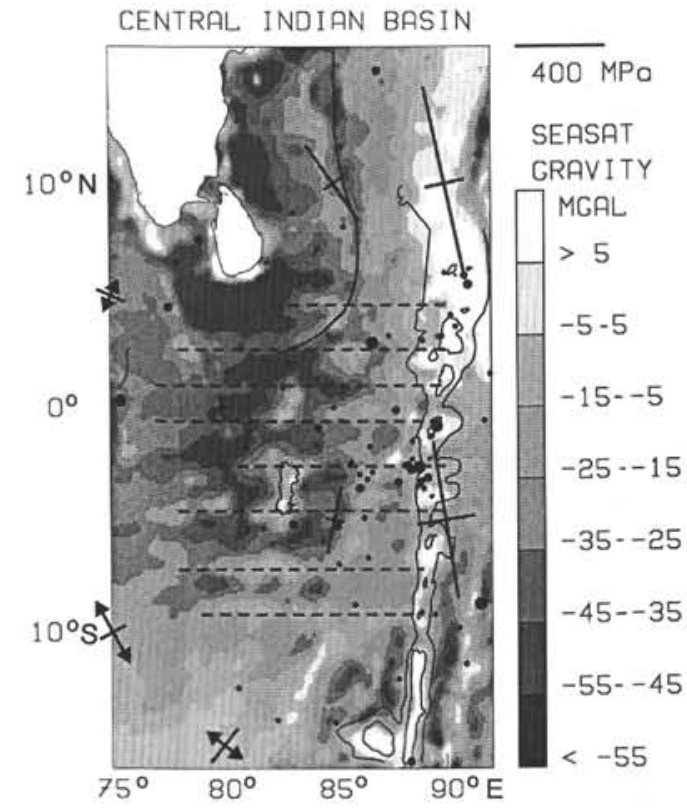

Figure 14. "Intraplate" earthquakes, gravity, and stresses (Fig. 12) for the Central Indian Basin and Ninetyeast Ridge. The highs on the Ninetyeast Ridge appear to be a continuation of the pattern from the Central Indian Basin to the west. Fracture zone trends from Sclater and Fisher (1974) and Liu et al. (1983). (From Stein et al., 1989). 


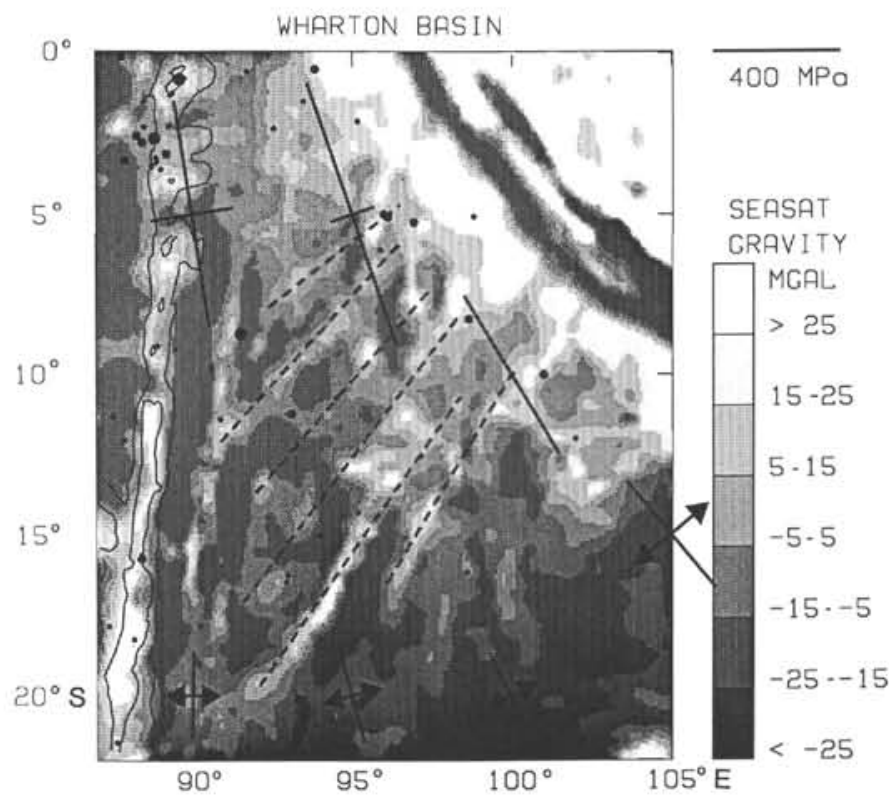

Figure 15. "Intraplate" earthquakes, gravity, and stresses (Fig. 12) for the Wharton Basin. The northeast to southwest trend of the fold highs (dashed lines) are significantly different from the east- to west-trending highs in the Central Indian Basin.

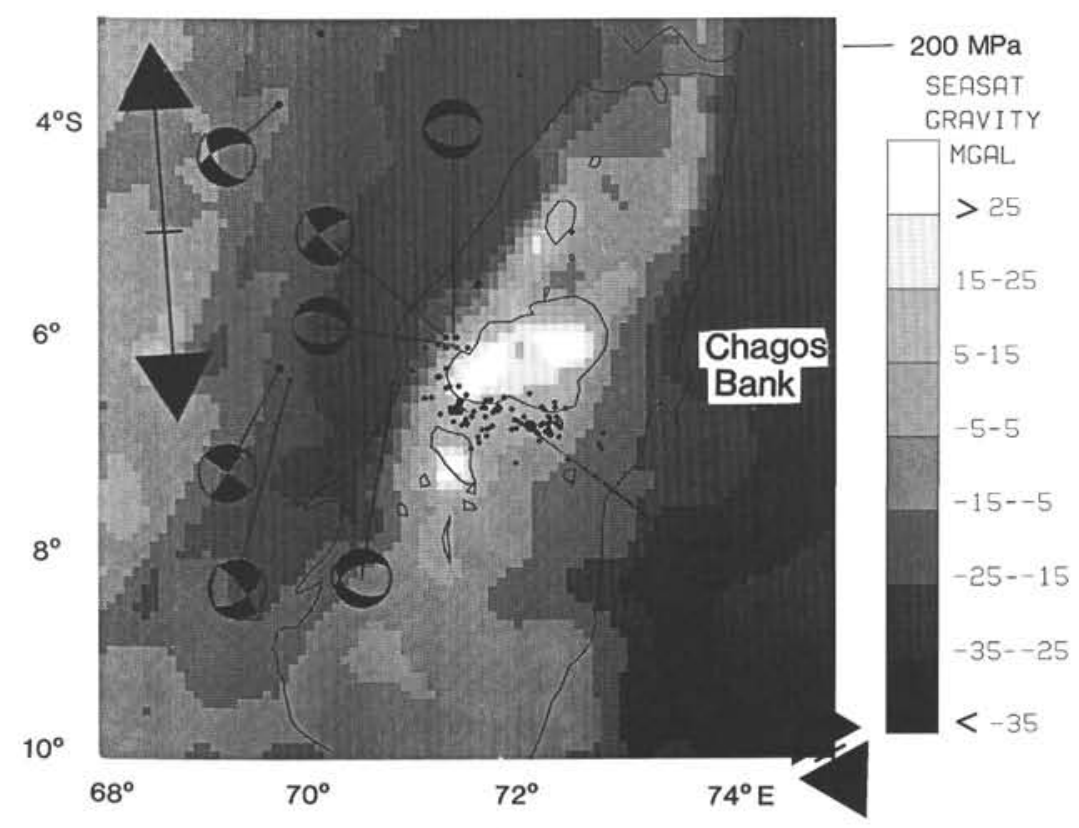

Figure 16. "Intraplate" earthquakes, gravity, stresses, and focal mechanisms (from Fig. 1) for Chagos Bank region of the southern Chagos-Laccadive Ridge. The $200-\mathrm{m}$ and $3500-\mathrm{m}$ contours are given for reference. 


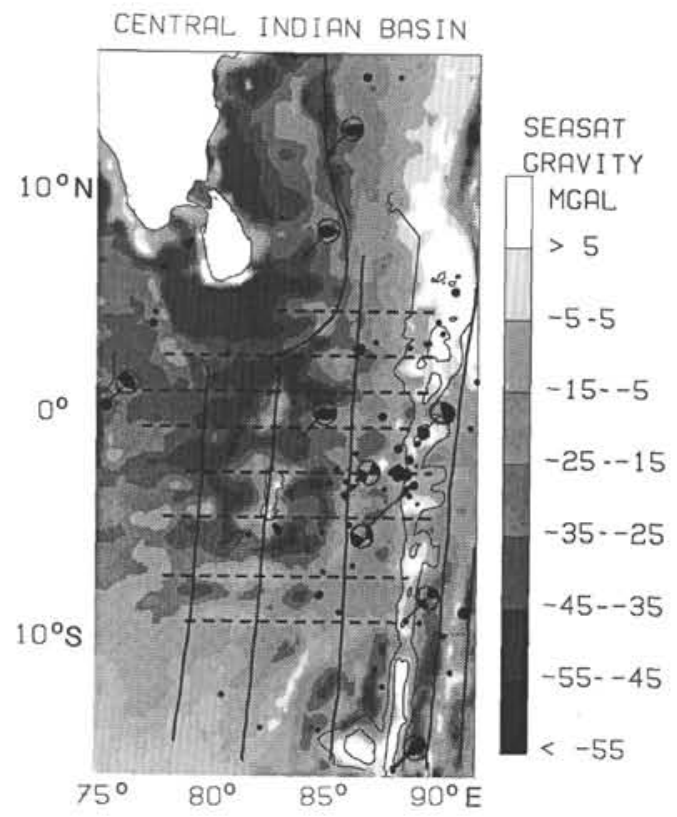

Figure 17. Gravity, fold locations, earthquake epicenters, focal mechanisms (from Fig. 1), and fracture zones Fisher and Sclater, 1974; Liu et al., 1983) for the Central Indian Basin.

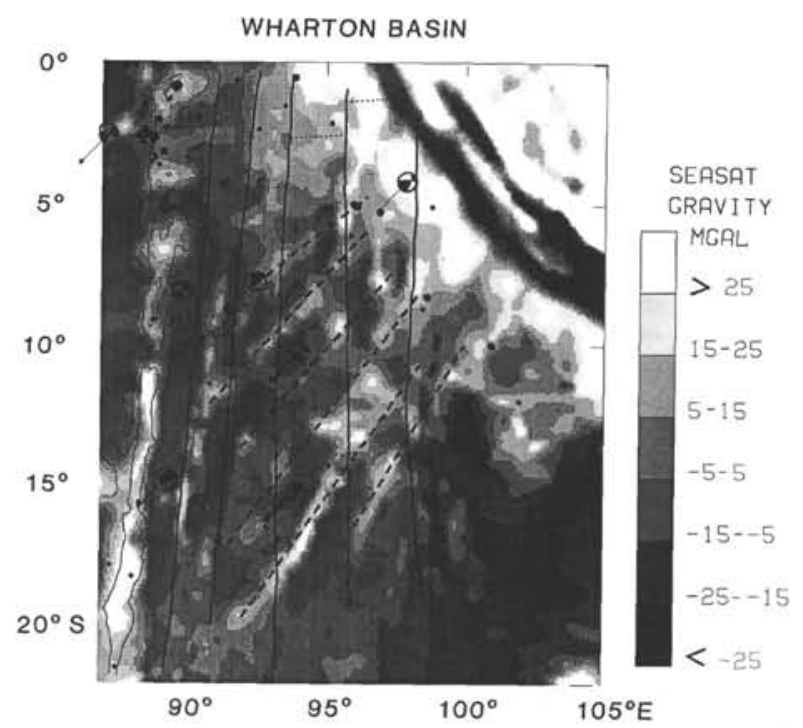

Figure 18. Gravity for the Wharton Basin, fold locations, earthquake epicenters, focal mechanisms (from Fig. 1) and fracture zones (Liu et al. 1983).

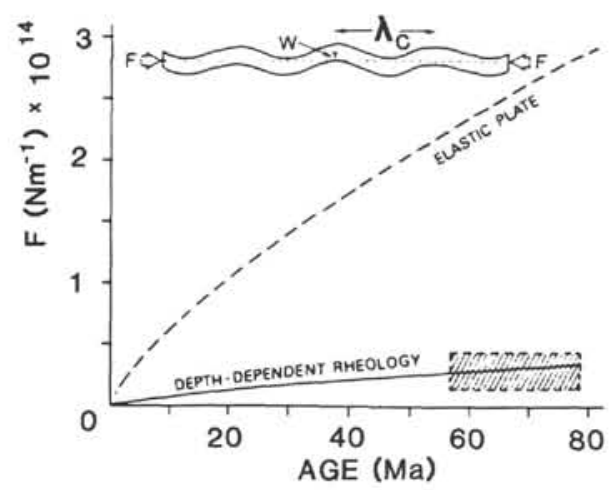

Figure 19. Buckling load vs. age of lithosphere with a depth-dependent rheology inferred from rock mechanics (Goetze and Evans, 1979) given by the solid line, and for fully elastic oceanic lithosphere given by the dashed line (McAdoo and Sandwell, 1985). Compressional forces calculated by Cloetingh and Wortel (1985) for the northeastern Indian Ocean (box) agree with forces required to buckle lithosphere where folding of oceanic lithosphere has been observed. 